Linköping University Medical Dissertation No. 1421

\title{
Activating the Sick-Listed
}

\section{Policy and Practice of Return to Work in Swedish Sickness Insurance and Working Life}

\section{Ida Seing}

National Centre for Work and Rehabilitation

Department of Medical and Health Sciences

Linköping University

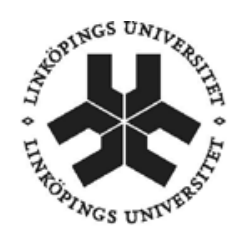

Linköping University

FACULTY OF HEALTH SCIENCES

Linköping 2014 
(C) Ida Seing, 2014

Printed in Sweden by LIU-Tryck, Linköping, 2014 ISBN 978-91-7519-232-1

ISSN 0345-0082 
To the memory of my beloved father, Bunhau Seing, who is always with me 


\section{Table of Contents}

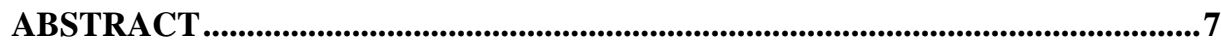

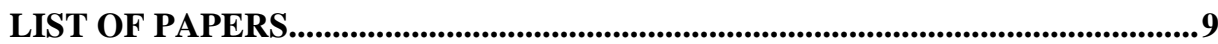

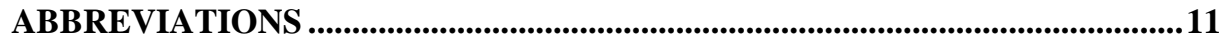

PREFACE ............................................................................................................13

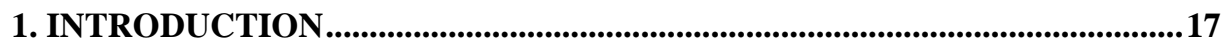

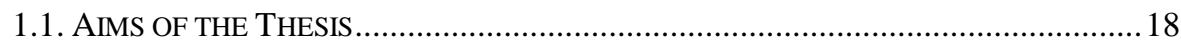

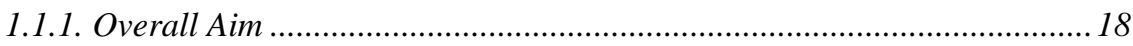

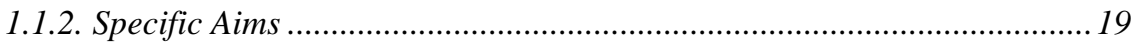

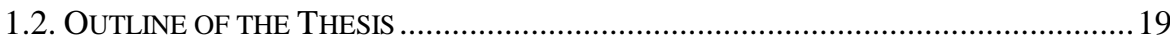

2. ON THE WELFARE STATE .............................................................................21

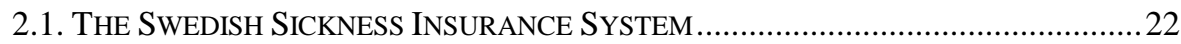

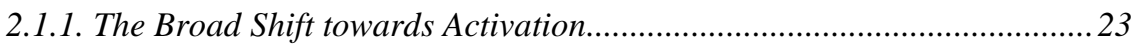

2.1.2. The Transformation of the Sickness Insurance System.............................. 23

2.1.2.1. Integration of Social and Labour Market Policies and the

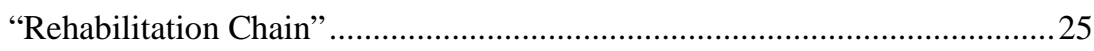

3. RETURN-TO-WORK RESEARCH AND WORK DISABILITY

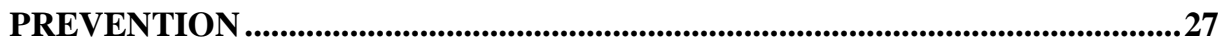

4. A THEORETICAL FRAMEWORK.................................................................29

4.1. RETURN TO WORK AS AN ORGANIZATIONAL FIELD ………………………..........2

4.2. INDIVIDUALIZATION OF SOCIAL RESPONSIBILITY ................................................ 31

4.3. STREET-LEVEL BUREAUCRACY AND ORGANIZATIONAL GOVERNANCE ...............32

5. A METHODOLOGICAL FRAMEWORK .............................................................33

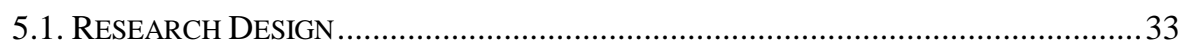

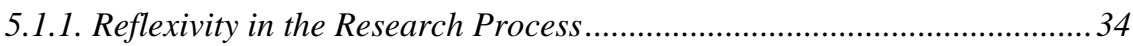

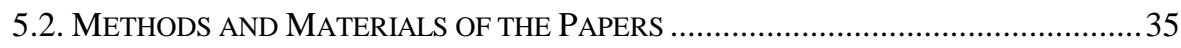

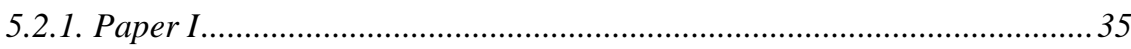

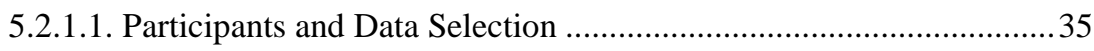

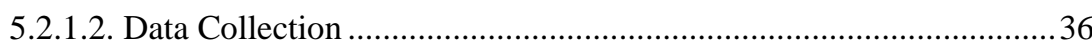




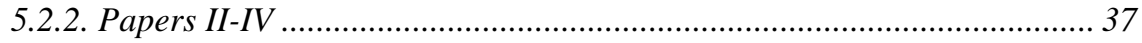

5.2.2.1. Participants and Data Selection .......................................................... 37

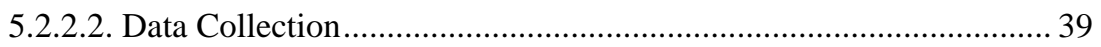

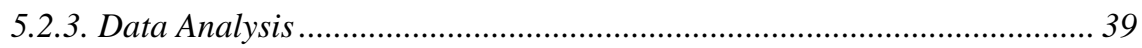

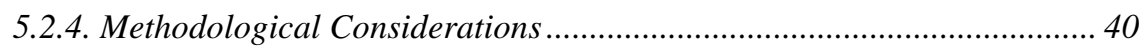

5.2.5. Ethical Considerations............................................................................. 41

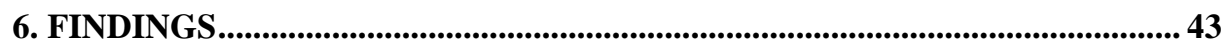

6.1. Paper I: Policy and Practice of Work Ability: A Negotiation of RESPONSIBILITY IN ORGANIZING RETURN TO WORK................................................ 43

6.2. PAPER II: EARLY-RETURN-TO-WORK IN THE CONTEXT OF AN INTENSIFICATION OF WORKING LIFE AND CHANGING EMPLOYMENT RELATIONSHIPS ........................... 45 6.3. PAPER III: RETURN TO WORK OR JOB TRANSITION? EMPLOYER DILEMMAS IN TAKING SOCIAL RESPONSIBILITY FOR RETURN TO WORK IN LOCAL WORKPLACE

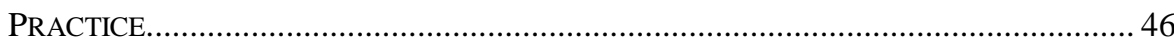
6.4. PAPER IV: ACTIVATION POLICIES AND SICK-LISTED WORKERS' EXPERIENCES AND TRUST IN THE SicKNESS INSURANCE SYSTEM IN LOCAL PRACTICE.................... 48

7. ACTIVATING THE SICK-LISTED................................................................ 49

7.1. ORGANIZATIONAL BOUNDARIES IN RETURN TO WORK ....................................... 49

7.2. DEMANDING ACTIVATION POLICIES AND SICK-LISTED WORKERS' LACK OF

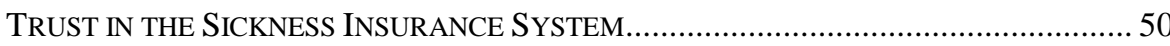

7.3. TENSION BETWEEN ACTIVATION POLICIES AND AN INTENSIVE WORKING LIFE. 51

7.4. EMPLOYERS AND THE WORKPLACE AS THE MISSING LINK................................. 53

7.5. INDIVIDUALIZATION AND THE ACTIVE SICK-LISTED WORKER AS AN IDEAL....... 54

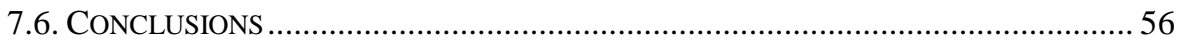

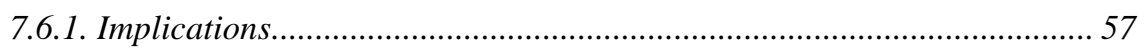

8. SVENSK SAMMANFATTNING ........................................................................ 59

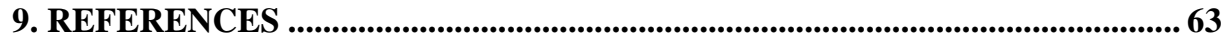





\section{Abstract}

A critical task of social policy in most Western welfare states during recent decades has consisted of reducing the economic burden on society due to sick leave, by stimulating participation in the labour market. Many jurisdictions have introduced activation policies, based on the premise that work "per se" has a therapeutic effect on sick-listed workers. People are expected to be "active", rather than "passive", recipients of financial benefits. However, there is limited knowledge of how activation policies focusing on return to work (RTW) are carried out in local practice. Against this background, the overall aim of this thesis is to study the local practice of activation policies by analysing how they are received, implemented and experienced by welfare state organizations, employers and sick-listed workers. The analysis has been influenced by theories concerning organizational fields, individualization, streetlevel bureaucracy and organizational governance.

In this thesis, the overall aim is investigated in four interrelated papers. In Paper I, the aim is to analyse the perspectives of stakeholders (i.e. welfare state actors and employers) on work ability by studying multi-stakeholder meetings. Paper II sheds light on activation policy, focusing on early RTW in the context of modern working conditions; the aim is to analyse RTW practice in local workplace contexts, in relation to Swedish early-RTW policy. The third paper focuses on employers, with the aim of analysing their role and activities regarding RTW, in local workplace practice. In Paper IV, the aim is to analyse sick-listed workers' experiences of the sickness insurance system in their contact with the Swedish Social Insurance Agency (SSIA) and their front-line staff.

The empirical material comprises two empirical studies: 1) audio-recorded multi-stakeholder meetings from regular practice $(\mathrm{n}=9)$ and 2$)$ semi-structured interviews with sick-listed workers and their supervisors in 18 workplaces $(n=36)$. The analyses of the material have been performed in accordance with the principles of qualitative content analysis. 
Main findings of the papers reflect strong organizational boundaries in the implementation process of activation policies. Welfare state actors and employers appear to be governed by their own organizational logics and interests, so the actors involved fail to take a holistic view of sick-listed workers and do not share a common social responsibility for individuals' RTW. This thesis illustrates how current activation policies focusing on RTW are based on a rather idealized image of the standard workplace. There is an explicit or implicit assumption that employers and work organizations are able to welcome sick-listed workers back to work in a healthy way. However, the intensity of modern working life leaves limited room for accommodating people with reduced work ability, who are not considered to have a business value to the workplace. In several cases, findings indicate that the SSIA's focus on activation and early RTW clashes with the financially oriented perspective of employers. Economic considerations regarding their business take precedence over legal and ethical considerations, and employers have difficulty taking social responsibility for RTW. Sick-listed workers are encouraged to adjust to new workplace settings and environments to meet the demands of the workplace, and, if RTW is not possible, to the demands of the labour market.The findings also show that sick-listed workers experience that contacts with the SSIA are 'standardized'; i.e., they perceive that the officials are loyal to demands in their organizations rather than being involved actors who support workers' individual needs. Sick-listed workers clearly experience that measures in Swedish activation policies have a strong focus on demanding aspects (financial work incentives) and less on enabling aspects (investments in skills).

Overall, this thesis illustrates an emerging social climate where sick-listed workers are positioned as active agents who must take responsibility for their sick leave and their RTW process. In a Swedish context, RTW is a matter of activating the sick-listed rather than activating the workplace.

Keywords: Activation policies, social policy, return to work, sickness insurance, working life, employers, street-level bureaucracy, individualization 


\section{List of Papers}

I. Seing I, Ståhl C, Nordenfelt L, Bülow P, Ekberg K. (2012). Policy and Practice of Work Ability: A Negotiation of Responsibility in Organizing Return to Work. Journal of Occupational Rehabilitation. 22(4):553-64

II. Seing I, MacEachen E, Ståhl C, Ekberg K. (2014). Early-Return-to-Work in the Context of an Intensification of Working Life and Changing Employment Relationships. Journal of Occupational Rehabilitation. DOI: 10.1007/s10926014-9526-5

III. Seing I, MacEachen E, Ekberg K. Ståhl C. Return to Work or Job Transition? Employer Dilemmas in Taking Social Responsibility for Return to Work in Local Workplace Practice. Disability and Rehabilitation. DOI:10.3109/09638288.2014.978509

IV. Seing I, MacEachen E, Ekberg K. Ståhl C. Activation Policies and SickListed Workers' Experiences and Trust in the Sickness Insurance System in Local Practice. Manuscript 


\section{Abbreviations}

EU: European Union

NPM: New Public Management

OECD: Organisation for Economic Co-operation and Development

RTW: Return to work

SPES: Swedish Public Employment Service

SSIA: Swedish Social Insurance Agency

WHO: World Health Organization 


\section{Preface}

I have now reached the end of writing my thesis and I would like to express my gratitude to the many people who have supported me along the way.

First and foremost, my thanks go to my supervisor Kerstin Ekberg. I really appreciate all the knowledge and encouragement you have given me, and for always being more than 100 percent present while I have been working on my thesis. I will be forever grateful to you for giving me the opportunity to do what I really want to do! My deepest gratitude also goes to my co-supervisor Christian Ståhl. I am indebted to you for all the inspiring discussions we have had, which have given me energy in writing my thesis. Many thanks for all your knowledge, your constant support and commitment! And to Ellen MacEachen, my co-supervisor, thank you for your generosity and enthusiasm in my thesis project. I have been so lucky to have you as a supervisor and I am very grateful for everything I have learned from you. Furthermore, I want to thank Lennart Nordenfelt for his involvement during the first years of my $\mathrm{PhD}$ studies. Lennart, it was a privilege to have you as a supervisor, and thank you for all your constructive and encouraging comments on my thesis. My thanks are also due to Björn Johnson and Gunnel Östlund for your important comments and valuable advice on my research at my "half-way seminar".

And an important thank you to all the interviewees who have participated in the studies, for sharing valuable stories and experience, on which this thesis project is based.

I have been very fortunate in having such a good work environment. A big thank you to present and former co-workers at the National Centre for Work and Rehabilitation, especially to Karin Nordström, my constant PhD companion and office mate. I have really appreciated your company and friendship! Also special thanks to Anna-Carin Fagerlind Ståhl, for being there with good advice and encouragement. I would also like to thank my co-workers at the Division of Community Medicine for support and good company, especially during lunch- and coffee breaks. Further, I am very grateful to Marie Jansson. 
Thank you for your true concern, and for your wise advice regarding both my research and academic life. And Ann-Charlotte Nedlund, you have been an important sounding board for me during these years. Thank you for all your help and friendship! Also to Nathalie Eckard, for your encouragement and company, especially during lunches at the end of my thesis writing. Thank you so much!

There are people who have not been directly connected with the writing of my thesis at Linköping University, but have been important in different ways. Åsa Casula Vifell, I was so happy to have you as both a colleague and a friend. Thank you for all the knowledge you shared, for all the happy moments and for always being there. Kerstin Jacobsson, I am so grateful to you for being a source of inspiration, and for all the knowledge I have gained from you. Thank you for your genuine enthusiasm and encouragement since I entered the academic world! And Julia Peralta Prieto, I have so appreciated all the inspiring discussions we have had over the years, and I am looking forward to our future collaborations! I would also like to express a collective thank you to my former co-workers at the Stockholm Centre for Organizational Research, particularly to Christina Garsten, who initially sparked off my interest in social and labour market policies. Thank you for all your knowledge and inspiration! Daniel Castillo, I really appreciate your support over the years, both in the academic field and as a friend. Ignacio Concha-Ferreira, many thanks for all of our inspiring and fun talks at conferences and seminars over the years.

During my PhD studies I had the privilege of taking part in the Work Disability Prevention CIHR Strategic Training Program at the University of Toronto. A special thank you to Patrick Loisel, the program director, and to Sandra Knol, the program coordinator, for your commitment! And to Linda Åhlström, for your company and happy moments in Toronto. In spring 2013 I also had the opportunity to visit the Institute for Work \& Health in Toronto for three months. I want to thank my fellow colleagues for a stimulating time in your work organization, both on a professional and a personal level.

Further, Hilary Hocking, thank you for your professional and skillful language revision of this thesis. 
And to all my kind friends who have been so supportive, with special thanks to Emma, Ida, Leo, Rebecka and Sandra, thanks for always being there for me!

Finally, my deepest gratitude goes to my dear family: my mother AnnChristine, my sisters Anna and Sara and their families, and my grandmother Marianne. I am so lucky to have you all! Mamma, thank you for your endless and unconditional love and concern; for being there through thick and thin! And last but not least, I want to express my thanks to Eddie and his kind family. Eddie, I am so happy that you went to "that party", and that I now have the privilege of spending my life with you.

\section{Ida Seing}

Linköping, 13 November 2014 


\section{Introduction}

A critical task of social policy in most Western welfare states during recent decades has been to reduce the economic burden on society due to sick leave, by stimulating labour market participation [1-4]. Many jurisdictions have introduced activation policies, based on the premise that work "per se" has a therapeutic effect, leading to good health and well-being [5]. A common statement in policy documents is that the longer people are off work due to illness, the less likely it is that they will return to work [6, 7]. This development reflects a shift of focus from "passive" compensation to "active" work reintegration. Sick-listed people are expected to be active, rather than passive, recipients of financial benefits, and instead of disability or impairment, the focus is on the individual's ability to work [8-10]. At policy level, activation policies have gained strong support, and activities that prevent the "disability benefit trap" [2] are favoured by international organizations such as the OECD and EU as well as national governments $[1-3,8,10]$. As is underlined in a report from the OECD:

To improve the integration of disabled persons, societies need to change the way they think about disability and those affected by it. The term "disabled" should no longer be equated automatically with "unable to work". Disability should be recognised as a condition, but it should be distinct from eligibility for, and receipt of, benefits, just as it should not automatically represent an obstacle to work. A disabled person's health status should, if necessary, be retested at regular intervals, independently of whether or to what extent the person is working. $[1,156]$.

In a Swedish context, this activation approach has facilitated a social policy that encourages sick-listed workers to change jobs and be mobile in working life. In 2008 the so-called "rehabilitation chain" (based on stricter activating principles with an end point of entitlement to sickness benefits) was introduced in sickness insurance. One of the aims was to facilitate early RTW by increasing the "transition" of sick-listed people from sick leave to the labour market. Job transition is described in positive terms; changing jobs is seen as a solution to sickness absence, in that a better match or fit between the sick- 
listed individual's work ability and existing jobs on the labour market is expected to be achieved [6, 7]. Sick leave as the start of a transition process is explicitly articulated in the following governmental report:

In the second place, it is important that sick leave becomes the start of a transition process. In successful cases, there can be a direct transition from sick leave to a new job, and in other cases a period of unemployment may be required before the goal is reached. In all cases, transition is preferable to continued sick leave and ultimately disability pension. The task of the insurance systems is to facilitate transition [...] [7, 62]

However, there is limited knowledge on how activation policies focusing on RTW are received and carried out in local practice. The consequences of these policy changes in local practice (including individuals, welfare state organizations and employers) are an important topic for further analysis. Previous research indicates that focus on activity and work reintegration of sick-listed individuals makes heavy demands on those organizations (the SSIA, healthcare, employers, the SPES, and municipalities) that are required to implement activation policies. The organizations involved demonstrate difficulties in cooperating and sharing responsibility for the individual in RTW [1113]. Further, research indicates that contemporary working life is characterized by work intensification, with an increase in reorganizations, downsizing and layoffs in work organizations [14-18]. This raises questions concerning the conditions in today's working life for sick-listed individuals to return to work. Against this background, this thesis focuses on the local practice of activation policies.

\subsection{Aims of the Thesis}

\subsubsection{Overall Aim}

The overall aim of this thesis is to study the local practice of activation policies by analysing how they are received, implemented and experienced by welfare state organizations, employers and sick-listed workers. Hence, the focus is both on those actors who are to implement the policies (welfare state 
organizations and employers), and on sick-listed workers whose daily life is affected by these decisions. The studies are performed from different perspectives at a local level.

\subsubsection{Specific Aims}

The overall aim of this thesis is investigated in four interrelated papers. The papers each have a specific aim related to the overall aim of the thesis. The aim of the first paper is to analyse the perspectives of stakeholders (welfare state actors and employers) on work ability, by studying multi-stakeholder meetings. The second paper sheds light on activation policy, focusing on early RTW in the context of modern working conditions; the aim is to analyse RTW practice in local workplace contexts, in relation to Swedish early-RTW policy. The focus of the third paper is on employers, the aim being to analyse their role and activities in local workplace practice, with regard to RTW. Finally, in Paper IV, the aim is to analyse sick-listed workers' experiences of the sickness insurance system in their contact with the SSIA and their front-line staff.

\subsection{Outline of the Thesis}

This thesis is structured in the following order. In chapter 2, research on different types of welfare systems is described; and the Swedish sickness insurance system is presented, focusing on how the system has developed during the last few decades. In chapter 3, research on RTW and work disability prevention is described. In chapter 4 , theoretical perspectives underlying this thesis are presented, and in chapter 5 the methodological framework is described. In chapter 6 , the main findings of each paper are presented. In chapter 7 , the findings are discussed and elaborated in relation to the theoretical framework; the chapter ends with overall conclusions and implications for further research and policies. Finally, chapter 8 contains a Swedish summary of the thesis. 


\section{On the Welfare State}

Research on welfare systems is a broad field, in which academic disciplines such as sociology, political science and economics are represented. The main focus in research on welfare systems is often on classifications of different types of welfare states in terms of their approaches to securing welfare for their citizens, and how systems have changed over time. In order to understand the function of the welfare state in different countries, decommodification constitutes a central concept [19]. De-commodification represents the extent to which individuals in a welfare state can maintain a socially acceptable standard of living without being reliant on selling their labour on the market to survive (e.g. in times of illness, unemployment and ageing).

In his highly cited book The Three Worlds of Welfare Capitalism [19], the Danish sociologist Gosta Esping-Andersen categorized welfare states into three different regimes: 1) liberal welfare regimes, 2) corporative welfare regimes and 3) social democratic welfare regimes.

In liberal regimes, the state has a minimal role in providing its citizens with welfare. In these regimes, the market has a dominant role, and public solutions are primarily chosen when market- and family-based solutions have failed. De-commodification is low, due to modest social benefits that usually involve means testing. Examples of liberal regimes are the United States, Canada, Australia and the United Kingdom.

In corporative welfare regimes, social benefits are usually earnings-related and administrated by the employer. Hence, entitlement to benefits is closely related to position on the labour market. The role of the family is emphasized, and the state may guarantee individuals' welfare when other institutions (e.g. the family) have failed. Examples of corporative regimes are Germany, France, Italy and Austria.

Social democratic welfare regimes are based on principles of universalism, where social welfare is connected to citizenship covering the entire population. Social insurances are collectively funded by taxes and governmental 
welfare institutions and have far-reaching responsibilities for the welfare of citizens, in providing income security for the socially disadvantaged. These regimes are characterized by a high level of de-commodification, in terms of having a comparatively generous benefit system, a low level of means testing, and active labour market policies. Examples of social democratic regimes are found in the Scandinavian countries [19].

\subsection{The Swedish Sickness Insurance System}

The Swedish sickness insurance system is universal and based on the principle of citizenship; income security is regarded as a social right [20]. The system offers income replacement without means testing, and individuals are entitled to sickness benefits regardless of the causes of their disability. The system is funded by taxes and employer fees.

The Swedish Social Insurance Agency (SSIA) is a governmental authority which is formally responsible for administrating and coordinating sickness insurance and return to work. The SSIA is responsible for decisions regarding individuals' entitlement to sickness benefits, for setting up a rehabilitation plan, and for cooperating with other stakeholders such as healthcare professionals and employers. Other organizations such as the Swedish Public Employment Service (SPES) and municipalities are also involved.

Social insurance officials' assessments of entitlement to sickness benefits are based on sickness certificates issued by physicians. To be eligible for sickness benefits, three conditions need to be fulfilled. Firstly, there must be a medical diagnosis, which secondly implies a reduction in the individual's functional capacity. Thirdly, this reduction must imply at least 25\% work disability [21]. In the assessment of work ability, social or financial circumstances must not be taken into account [22]. 


\subsubsection{The Broad Shift towards Activation}

In recent welfare and labour market reforms in Europe and North America, there is a general trend towards activation. There has been a shift of focus from income security as the main aim of labour market participation. Today, activation is a common orientation in both labour market and social policies, and covers many social benefits schemes, such as unemployment insurance, disability schemes and social allowances $[8,10]$. Although there is considerable variation regarding the design and intensity of activation across national models, it is clear that a common and basic objective is to quickly re-integrate people who are without jobs, taking them from inactivity (social exclusion) into working life [10]. Two aspects of activation policies are highlighted in research: one is "enabling" in terms of focusing on investments in individuals' skills (work ability/employability), and the other is "demanding" in its emphasis on strict financial work incentives by reducing dependency on social benefits [23]. In national activation policies, these may be balanced differently [24].

\subsubsection{The Transformation of the Sickness Insurance System}

Activation policies designed to re-integrate people who were on long-term sick leave into the labour market were introduced in the early 1990s in Sweden. The so-called "work principle" [25], which for a long time had been a central element in Swedish labour market policy was intended to introduce a similarly active element into social policy in order to counter long-term sickness absence and promote return to work [26]. Instead of passive measures in terms of financial benefits, people were also to be offered active measures, such as part-time sick leave, work training and work accommodation. In 1991, the regulative responsibility of employers for their workers on sick leave was expanded and legally clarified. This meant that employers were formally required to investigate sick-listed workers' rehabilitation needs, and to organize workplace adjustments and measures in order to stimulate return to work. During this period of time, employers also became required to pay workers sick pay during the first 14 days of illness. These changes were designed to increase employers' incentives and willingness to reduce the number of peo- 
ple on sick leave, and invest in the work environment in order to ensure workers' health [26]. In 2007, the responsibility for employers to produce rehabilitation plans was again abolished; however, the responsibility for workplace accommodations remains.

During recent decade, Swedish social policy has undergone substantial changes, with the implementation of stricter activation principles in sickness insurance [27]. The role of the welfare state has taken on a more controlling and administrative function; the main role of the SSIA today is to assess individuals' entitlement to sickness benefits and to a lesser extent to engage in rehabilitation and coordination of RTW interventions. Target groups for activation during the last decade have mainly been welfare state organizations and sicklisted workers. Welfare state actors such as the SSIA, healthcare professionals (mainly physicians) and the SPES have been subject to change in terms of reorganizations, efforts to standardize work ability assessments and the establishment of public cooperation to stimulate RTW [12, 28]. With the aim of reducing the number of people on sick leave, stricter activating principles have been implemented in the sickness insurance system, with time limits comprising a pre-defined schedule for RTW [29]. The replacement rates for loss of income have been correspondingly reduced [30]. There has been a greater emphasis on the responsibilities of the individual towards society, and access to social security is increasingly connected with work and activity. In Sweden, a focus on activation articulates a new demanding direction in policy, with a new conceptualization of the work principle emphasizing people's "duty" to return to work [25]. At the policy level, the increased responsibility of the individual for his/her sick leave and RTW has been clarified:

The insured person should have greater responsibility than previously for his/her work ability, and should take the initiative and ask for measures at the workplace which may result in him/her being able to return to work. [6, 64]

In the light of this development, a recent governmental report has questioned whether Sweden is a country that can still be classified as a social democratic regime [30]. 


\subsubsection{Integration of Social and Labour Market Policies and the "Re- habilitation Chain"}

In policy documents it is apparent that the former sickness insurance (until 2008) was seen as too "soft" and generous in terms of financial compensation $[6,7]$. Causes underlying high levels of sickness absence were found in individuals who overexploited the sickness insurance system [31]. Against this background, policy makers emphasized a need to increase the mobility or flow of people from sick leave to the labour market, either to their previous job, to a new job or to unemployment, by entering a "labour market introduction programme” offered by the SPES. Long-term sick leave was to be considered the start of a transition process - from sick leave to the labour market - and more sick-listed people were expected to change jobs when their current job could not be reconciled with their disease [6, 7]. Hence, a change of jobs or becoming unemployed was described in positive terms and seen as a solution to sickness absence. Transition and job change became a form of rehabilitation strategy, in that a better match or fit between the sick-listed individual's work ability and existing jobs on the labour market was expected to be achieved.

As a result of this policy process, the government introduced several changes in order to reform the sickness insurance system. In 2008, the rehabilitation chain was implemented in order to standardize the sick-leave process and facilitate early RTW. The reform consisted of stricter activation principles in terms of fixed time limits and an end point for entitlement to sickness benefits [29]. The rehabilitation chain is a reflection of how the idea of activation and early RTW had come to influence Swedish regulation of sickness insurance. By tightening up eligibility criteria and decreasing the level of income protection due to sick leave, the reform was thought to create financial incentives for early RTW and labour market participation for sick-listed workers.

The rehabilitation chain is a form of legislated working method applied by officials at the SSIA. It comprises a fixed time schedule for assessments of individuals' entitlement to sickness benefits. From day 1 to 14 , employers are responsible for providing sick pay. Thereafter (day 15-180), work ability is assessed in relation to any work task that the current employer has to offer. After six months (day 181-365), the assessment is broadened to include work ability in relation to the labour market at large. Therefore sickness benefits 
may end after six months if a person is considered able to work in another job. During the first year, sickness benefits are set at approximately $80 \%$ of wages. After 365 days, prolonged sickness benefit at a lower level (approx. 75\% of wages for a maximum of 550 days) may be granted to sick-listed people with severe disorders after a renewed application. After this period, a labour market introduction programme is offered by the SPES. The programme lasts for a maximum of three months, after which it is once again possible to apply for sickness benefits [32]. 


\section{Return-to-Work Research and Work Dis- ability Prevention}

The importance of early-RTW activities to counter sickness absence is strongly reflected in scientific literature on work disability prevention and RTW [5]. For example, the much cited work of Waddell \& Burton [4] concludes that in general, work is good for sick-listed peoples' health and well-being:

Yet, overall, the beneficial effects of work outweigh the risks of work, and are greater than the harmful effects of long-term unemployment or prolonged sickness absence. Work is generally good for health and wellbeing. [4, 38]

Studies indicate that the resumption of work before full health is recovered may have a rehabilitative function, and does not necessarily increase symptoms [33-36]; however, other studies show that sustainability in work ability may be dependent on diagnosis and workplace conditions [37]. Studies also show that the longer people are off work due to illness, the less likely it is that they will return [38, 39]. Further, systematic reviews of RTW interventions identify how early rehabilitation and early contact with the workplace during the employee's sick leave can reduce the number of lost working days and associated costs of compensation [40, 41]. Modified work programmes are shown to facilitate employees' RTW and reduce the number of lost working days [42]; and supervisory training in communication skills and ergonomic adjustments is found to reduce the number of new injury claims [43].

However, most studies of RTW have been based on planned interventions, usually with willing work organizations and employers. Past intervention studies of RTW have also adopted different definitions of RTW in terms of time period (e.g. return for a short or longer period of time), different ideas regarding what "work" the sick-listed people are returning to (e.g. former job or new workplace setting) [44]. Hence, an understanding of how RTW plays out in natural conditions is scarce, and a common definition of what constitutes "re- 
turn" and "work" remains elusive [44, 45]. A differentiation in RTW interventions due to for example age, sex and diagnosis seems to be needed but this is scarcely studied [46]. Against this background, there has been only a limited focus on long-term outcomes such as the sustainability of RTW, or how the interventions are received and experienced by workers and employers who are affected. The definition of what counts as successful RTW may vary depending on the specific interests and concerns of the actors involved [41]. Therefore, conditions for the successful implementation of early-RTW measures and their effectiveness in practice are a major challenge and may be questioned [45].

However, there is growing research interest in the implementation of evidence-based RTW interventions [47]. There are studies that acknowledge the implementation process of RTW programmes and policies, and focus on the complexity of multi-stakeholder involvement [11, 48-50]. There is also an emerging interest and literature concerning the way in which workplaces influence the practice of RTW [51-56]. In this context, the influence of support from supervisors [57] and co-workers has been identified as crucial for successful RTW [58, 59]. 


\section{A Theoretical Framework}

In this thesis, the analysis is characterized by a combination of inductive and deductive elements, where theoretical perspectives and empirical material constitute integrated parts in the interpretation of "social reality". The main focus is on the practice of activation policies by analysing how they are received, implemented and experienced by the actors involved at local level. In order to study the practice of activation policies, three main theoretical approaches are central: 1) the theory on organizational fields, 2) theories on individualization and 3) theories on street-level bureaucracy and organizational governance. In the following chapter these theories are described in greater depth and placed in the context of activation policies and RTW.

\subsection{Return to Work as an Organizational Field}

According to Lindqvist [26], RTW is carried out in the intersection of three main arenas: 1) the public authority arena (the SSIA, the SPES and municipalities etc.), 2) the medical arena (healthcare) and 3) the production arena (employers, unions, occupational healthcare). Against this background, the theoretical concept of organizational fields (from neo-institutional theory) is suitable [60, 61]. An organizational field is defined as a "sets of organizations that together accomplish some task in which a researcher is interested" [62, 148].

Return to work can be considered a complex field, since several organizations with different tasks, rules and logics are represented. In addition to the sicklisted worker, actors such as the SSIA, healthcare and occupational healthcare professionals, the employer, the SPES and the social services are involved. Based on regulations and a medical certificate, the SSIA decides on the individual's entitlement to sickness benefits and rehabilitation measures from the sickness insurance system. From the perspective of healthcare professionals (physicians), the task is to identify and assess whether there is a disease or injury that affects the individual's work ability. Based on work environment 
legislation, employers are required to make workplace adjustments in order to promote the sick-listed employee's RTW.

According to Scott and Meyer [60], an organizational field is characterized by the existence of a community of organizations which have a common purpose, where the actors participate and frequently interact with each other more than with actors outside the field. The organizational field can be described as a network of different systems, organizations and logics. Policies are implemented in an interaction between various organizations from both the public and the private sphere which devote different amounts of time to the task in question. In these processes, both conflict and consensus between the actors involved might occur. And due to the actors' different organizational logics and interests, the organizational field is likely to include conflicts where negotiation processes, struggles and competition between the actors will occur [61]. In this context the concept of "domain claims" [26] is central; this is a term describing how competition between actors in the same organizational field may occur, in terms of taking care of or avoiding certain tasks and responsibilities. This can be illustrated in the organizational field of RTW, where the organizations involved have a great deal in common in terms of shared responsibility for the same individual, and in which they have different functions in the same work process [26]. While SSIA officials, healthcare professionals and SPES officials share the task of getting individuals back to work, they also represent organizations with their own goals and aims. Following the organizational logic of the SSIA, the individual is "sick-listed"; however, from the perspective of healthcare professionals, she/he is a "patient", and for the employer she/he is an "employee".

An organizational field arises when a dominant actor (usually the state) establishes rules that other organizations are required to follow [61]. Hence, the government has a central role in establishing an organizational field. In the case of RTW, this can be illustrated in the regulative responsibility of Swedish employers to organize workplace adjustments and rehabilitation for workers on sick leave in an "appropriate way". It is further stressed that the activities are to be organized in cooperation with the employee, union representatives, the SSIA and "other" relevant actors [63]. Another example of the importance of formal rules in the development of an organizational field is the formal obligation of employers to participate in "status meetings" held by the SSIA to 
discuss sick-listed individuals' work ability and rehabilitation needs. However, the degree of interaction between the organizations within the organizational field may differ over time [61].

\subsection{Individualization of Social Responsibility}

Individualization refers to a process where societal problems that were previously targeted on a structural level are redefined into individual problems, and where policies place the responsibility for solving them on the individual. As described in the introduction, activation policies have gained strong support at policy level and activities such as "training”, “empowerment” and "integration" of people with disabilities are favoured by governments and international organizations. A basic idea in a so-called active society is that all citizens (including most disabled people) are expected to contribute to the society's development. Activation is the responsibility of the individual but it is also a responsibility of society. As Holmqvist [9] describes it:

In the active society, integration and empowerment is an individual responsibility for the disabled person, but it is also a matter of concern for society, e.g., by way of various "welfare-to-work" programs for disabled people [...]. Hence, disabled persons are to be helped to "help themselves". [9, 211]

This development has been described as advanced liberal governance [6466], where the individual is seen as an active subject who becomes the object of interventions and change. The individual is encouraged to work on her "self" by introspection, reflexive self-evaluation, monitoring and reshaping of the self in accordance with current ideals [64-67]. Individuals are expected to have an "enterprising self" by showing entrepreneurial attitudes, being adaptable and flexible to changing circumstances [64-67]. In line with this, researchers refer to the term therapy society, where "experts on subjectivity" (e.g. rehabilitation professionals, coaches) have come to have a central role in both social and labour market policies [66, $68,69]$. Bureaucrats at local level function in a "coaching role", with the formal aim of identifying and mobilizing ability, and also motivating individuals to participate in their "own" RTW process. An example of this in a Swedish social policy context, is the introduction of "motivational inter- 
viewing” at the SSIA in order to improve the quality of officials' meetings with sickness benefit claimants [70]. In the context of labour market policy, this is exemplified by rehabilitation professionals such as occupational therapists, occupational psychologists and social welfare officers at the SPES, who have the task of investigating unemployed individuals' work ability [71].

\subsection{Street-level Bureaucracy and Organizational Governance}

Implementation of national social policies is carried out by the SSIA and their officials at local level. In this context, Michael Lipsky's theoretical framework regarding the importance of so-called "street-level bureaucrats" and their room for manoeuvre can be used to understand and explain the outcomes of social policies [72]. Street-level bureaucrats represent the lower hierarchy of the organization; they are the ones who have daily contact with clients, and they must perform their work tasks based on a tight budget, within the limits of laws and regulations [72, 73].

In many countries, street-level bureaucracy in welfare state organizations has been fundamentally reformed. During the last few decades, New Public Management (NPM) principles (e.g. management by objectives) have come to influence the day-to-day work of front-line staff [74-76]. Researchers have identified how organizational governance and control influences the contact and relations that front-line staff have with their clients [76]. There are demands on front-line staff from the higher levels of their organizations, but also from their environment such as the government [9, 66, 73, 77]. For example, the performance of front-line staff is measured and evaluated by the management of the organization and also by legislation [73]. Hence, the discretion of street-level bureaucrats is to a considerable extent restricted by structural limitations [73]. 


\section{A Methodological Framework}

The overall aim of this chapter is to describe in depth the methodological approach that has guided the work in this thesis. First, overall methodological approaches of this thesis are discussed. Thereafter, the methods and material of each separate paper are presented.

\subsection{Research Design}

As has been described earlier, this thesis is based on two different empirical studies which have generated four papers. The first empirical investigation comprises nine audio recorded multi-stakeholder meetings from regular practice (so-called status meetings), which resulted in Paper I. The second study consists of semi-structured interviews with sick-listed workers and supervisors, which resulted in Papers II, III and IV.

In qualitative research, reality and knowledge are often seen as a social construction, in that peoples' perceptions of any given social phenomenon are shaped in social contexts [78]. Against this background, qualitative interviewing was chosen as a central part of this thesis. The data collection (in Papers II, III and IV) is based on semi-structured interviews [79]. The interviews represent values and they give the researcher the opportunity to gain an insight into the world of the respondents. In qualitative research there is an emphasis on describing people's lives in their context [80]. In this thesis, the aim was to capture the interview participants' stories, perspectives and values around particular areas. The focus was on gaining a deeper understanding of, for instance, the way in which the participants interpret the sick-leave and RTW processes, and their contacts with welfare state actors. In both in-depth interviews and semi-structured interviews, it is important to be open to the way in which the interview develops. Hence, story-telling was encouraged during the interviews, constituting a strength with regard to obtaining rich material. The 
participants were given the opportunity to choose the focus and steer the conversation to what they considered to be important. On the other hand, this approach may involve a risk that interviews lose direction and focus. Therefore, an interview guide was developed based on the purpose of the study, covering broad themes and questions which guided the interviews [79].

In all papers, the analyses of the data were performed in accordance with the principles of qualitative content analysis [80,81]. The focus in the papers was on investigating the manifest and latent content of the empirical material and highlighting both the visible components and underlying meaning of the text [81]. In all papers, the analytical process can be described as being based on the method of abduction, since it has been characterized by a combination of inductive and deductive elements [80]. Overall, the analysis was characterized by interplay between theory and empirical data in order to interpret and understand "reality". In Paper I, the analysis was guided by theoretical definitions and perspectives of work ability. In Paper III, a theoretical model was identified to guide a more directed content analysis [82], where employer activities were categorized from economic, legal and ethical perspectives. From this model, the descriptive categories were mapped in relation to the theoretical concepts, and quotations were added in order to illustrate how these perspectives influenced employers' activities in RTW.

\subsubsection{Reflexivity in the Research Process}

Reflexivity is essential in the research process of qualitative research. It is important that the researcher reflects on his or her role in conducting research. A researcher must recognize, examine and understand how social background and assumptions can affect the research process. It is useful to keep the following three issues in mind during the research process [83]: 1) How does your own biography affect the research process? 2) What shapes the questions you chose to study, and your approach to studying them? 3) How does the specific social, financial, and political context in which you reside affect the research process at all levels? 
It is central to recognize that the researcher, just like the study objects, is a product of social influences in society [83]. In terms of power and authority as an interviewer, I play an important role during the interview situation. I have a research agenda, asking specific questions about what I am interested in. In a broad sense, my disciplinary background in political science has influenced the research process and what has been chosen for investigation, the findings and the framing of the discussion and the conclusions.

\subsection{Methods and Materials of the Papers}

\subsubsection{Paper I}

The first study focused on how different actors interpret, discuss and assess sick-listed individuals' work ability by analysing multi-stakeholder meetings (from regular practice) in which the sick-listed person, the SSIA and at least one additional stakeholder (for example, the physician, the employer, the SPES and the union) participated.

\subsubsection{Participants and Data Selection}

The empirical material consisted of nine audio recorded status meetings collected in 2007 and 2008 in Sweden. Stakeholders participating in the meetings were representatives from the SSIA, the SPES, healthcare, employers and, in one case, the union (see Table 1). Some workers were sick-listed and partially employed; others were sick-listed and unemployed. Initially, the ambition was to obtain a large variation with regard to sick-listed workers' gender, age, time on sick leave and diagnoses. However, it was more difficult than expected to achieve the sample criteria due to time limitations at the SSIA. In the light of this, all meetings available to the research study were included in this paper. 
Table 1: Descriptions of participants in the status meetings

\begin{tabular}{|c|c|c|c|c|}
\hline $\begin{array}{l}\text { Status } \\
\text { meeting }\end{array}$ & $\begin{array}{l}\text { Sex/age/employment/ } \\
\text { profession }\end{array}$ & $\begin{array}{l}\text { Length of } \\
\text { meeting }\end{array}$ & Participants & Health condition \\
\hline 1 & $\begin{array}{l}\text { Woman } 40 \text { years old } \\
\text { Employed/Child minder }\end{array}$ & $41 \mathrm{~min}$ & $\begin{array}{l}\text { SSIA/SL/ } \\
\text { Emp }\end{array}$ & Musculoskeletal \\
\hline 2 & $\begin{array}{l}\text { Woman } 61 \text { years old } \\
\text { Employed/Cook }\end{array}$ & $34 \mathrm{~min}$ & $\begin{array}{l}\text { SSIA/SL/ } \\
\text { Emp }\end{array}$ & Musculoskeletal \\
\hline 3 & $\begin{array}{l}\text { Woman } 47 \text { years old } \\
\text { Employed/Assistant nurse }\end{array}$ & $21 \mathrm{~min}$ & $\begin{array}{l}\text { SSIA/SL/ } \\
\text { Emp }\end{array}$ & Musculoskeletal \\
\hline 4 & $\begin{array}{l}\text { Man } 42 \text { years old } \\
\text { Unemployed/ Construction } \\
\text { worker }\end{array}$ & $28 \mathrm{~min}$ & $\begin{array}{l}\text { SSIA, SL/ } \\
\mathrm{HC} / \mathrm{SPES}\end{array}$ & Traumatic injury \\
\hline 5 & $\begin{array}{l}\text { Man } 46 \text { years old } \\
\text { Unemployed/chef }\end{array}$ & $34 \mathrm{~min}$ & $\begin{array}{l}\text { SSIA/SL/ } \\
\mathrm{HC}\end{array}$ & Musculoskeletal \\
\hline 6 & $\begin{array}{l}\text { Man } 50 \text { years old } \\
\text { Employed/decorator }\end{array}$ & $23 \mathrm{~min}$ & $\begin{array}{l}\text { SSIA/SL/ } \\
\text { Emp }\end{array}$ & Traumatic injury \\
\hline 7 & $\begin{array}{l}\text { Man } 57 \text { years old } \\
\text { Employed/ } \\
\text { Construction worker }\end{array}$ & $40 \mathrm{~min}$ & $\begin{array}{l}\mathrm{SSIA} / \mathrm{SL} / \\
\text { Emp/HC/ } \\
\text { Union }\end{array}$ & Musculoskeletal \\
\hline 8 & $\begin{array}{l}\text { Woman } 62 \text { years old } \\
\text { Unemployed/Cleaner }\end{array}$ & $20 \mathrm{~min}$ & $\begin{array}{l}\text { SSIA/SL/ } \\
\mathrm{HC}\end{array}$ & Musculoskeletal \\
\hline 9 & $\begin{array}{l}\text { Woman } 39 \text { years old } \\
\text { Employed/Preschool teacher }\end{array}$ & $110 \mathrm{~min}$ & $\begin{array}{l}\text { SSIA/SL/ } \\
\text { Emp/HC/ } \\
\text { Other }\end{array}$ & Mental trauma \\
\hline
\end{tabular}

SSIA: The Swedish Social Insurance Agency

SL: Sick-listed

SPES: The Swedish Public Employment Service

EMP: Employer

HC: Healthcare professional

\subsubsection{Data Collection}

The empirical material was collected by Pia Bülow (co-author of the paper), who took part in the status meetings as a non-participating observer. SSIA team managers were contacted and asked to invite SSIA officials to participate in the study. The status meetings lasted on average 40 minutes. The shortest meeting took 20 minutes and the longest 1 hour and 50 minutes. The audiorecorded meetings were transcribed verbatim and minor corrections in citations have been made to improve readability. Transcripts were edited so that 
potentially identifying information such as names, places and workplaces were modified or deleted entirely.

\subsubsection{Papers II-IV}

Papers II and III focus on RTW practices in local workplace contexts, by analysing employers' and sick-listed workers' views and experience. Paper IV focuses on sick-listed workers' experiences of the sickness insurance system in their contact with the SSIA and their front-line staff.

All papers are based on the same empirical study. Papers II and III are based on interviews with both sick-listed workers and their supervisors, while Paper IV is based on interviews with sick-listed workers only.

\subsubsection{Participants and Data Selection}

The empirical study is based on 18 cases of sick leave, where semi-structured interviews have been conducted with sick-listed workers and their supervisors separately in 18 workplaces. In total the data material consists of a total of 36 interviews that were conducted from 2012 to 2013. In order to include workers on long-term sick leave, the sick-leave cases were purposively selected based on the length of their sick leave (more than 60 days). The gender distribution among the sick-listed workers was 16 women and two men, and the supervisors consisted of 13 women and five men. The median age of the worker participants was 55 years, and for the supervisors it was 50 years. Workplaces from 16 public organizations and two private organizations were represented. Regarding the occupations of sick-listed workers represented in this study, there were nine assistant nurses, one high school teacher, four public officers, one engineer, one legal specialist and one administrator (see Table 2). Workers' diagnoses included a variety of physical and mental conditions. 
Table 2: Description of the participants in the study

\begin{tabular}{|c|c|c|c|}
\hline Case & Work Organization & $\begin{array}{l}\text { Worker } \\
\text { (gender, occupation) }\end{array}$ & $\begin{array}{l}\text { Manager } \\
\text { (gender, occupation) }\end{array}$ \\
\hline 1 & $\begin{array}{l}\text { Private company (Transport, } \\
\text { infrastructure) }\end{array}$ & $\begin{array}{l}\text { Male, Engineering/site man- } \\
\text { ager }\end{array}$ & Male, Unit manager \\
\hline 2 & Public authority & Male, Legal specialist & Female, Unit manager \\
\hline 3 & High school (municipality) & $\begin{array}{l}\text { Female, secondary school } \\
\text { teacher }\end{array}$ & Male, Principal \\
\hline 4 & Hospital (County council) & Female, Assistant nurse & Female, Unit manager \\
\hline 5 & Public authority & Female, Public officer & Male, Unit manager \\
\hline 6 & Hospital (County council) & Female, Assistant nurse & Female, Unit manager \\
\hline 7 & $\begin{array}{l}\text { Telecom company (Owned by } \\
\text { municipality) }\end{array}$ & Female, Administrator & Male, Managing director \\
\hline 8 & Elderly care (Municipality) & Female, Assistant nurse & Female, Unit manager \\
\hline 9 & Elderly care (Municipality) & Female, Assistant nurse & Female, Unit manager \\
\hline 10 & Public authority & Female, Public officer & Female, Unit manager \\
\hline 11 & Elderly care (Municipality) & Female, Assistant nurse & Female, Unit manager \\
\hline 12 & Elderly care (Municipality) & Female, Assistant nurse & Female, Unit manager \\
\hline 13 & Municipality & Female, Public officer & Female, Unit manager \\
\hline 14 & Elderly care (Municipality) & Female, Assistant nurse & Female, Unit manager \\
\hline 15 & Private bus company & Female, Bus driver & Male, Unit manager \\
\hline 16 & Elderly care (Municipality) & Female, Assistant nurse & Female, Unit manager \\
\hline 17 & Social care (Municipality) & Female, Assistant nurse & Male, Unit manager \\
\hline 18 & Public authority & Female, Public officer & Female, Unit manager \\
\hline
\end{tabular}

Access to sick-leave cases was carried out in two ways. The first was to obtain a list of names of 20 people identified by the statistical unit at the SSIA as sick-listed for more than 60 days. Letters were sent to these potential participants, informing them about the purpose of the study. They were ensured that participation was voluntary, and asked for permission to interview their employer. A consent form was enclosed with the letter, to be returned by the participants. Of 20 people contacted, three agreed to participate. The other strategy for accessing people on sick leave was through employer and union representatives. Letters were sent to 16 representatives (13 employers and three union representatives) asking if they could identify workers who had been on sick leave for more than 60 days, and who might be interested in participating in the study. Of these, five representatives (one union representative and four employer representatives) responded. They were informed about the study and that participation was anonymous in terms of person and work organization. Based on this request, representatives from employers (senior managers and human resource personnel) and unions identified and provided contact information for workers (and managers) who were interested in partic- 
ipating in the study. The interested sick-listed workers were contacted and informed about the purpose of the study; they were ensured that participation was voluntary, and asked for permission to interview their employer. A consent form was enclosed, to be signed by participants. In total, 15 participants were recruited through employers and unions.

\subsubsection{Data Collection}

The method of data collection was semi-structured interviews, which made it possible to maintain a thematic focus and compare interviews with each other. An interview guide was developed, covering questions regarding views on causes of sick leave, the employers' role during sick leave and RTW, and the role of welfare state actors such as the SSIA and healthcare professionals. In order to obtain rich material, each participant was also given the opportunity to expand on issues they considered important.

In all cases, the interviews with the worker were conducted first and the supervisor interview followed. The time lapse between the interview with the worker and their supervisor varied from around one week to three months. The interviews lasted from 45 minutes to over two hours and were conducted during personal meetings in public libraries, university facilities, workplaces and cafés, and took place in separate rooms and spaces where only the participant and the interviewer were present and could hear the dialogue. They were audio-recorded and transcribed verbatim; minor corrections in citations have been made to improve readability.

\subsubsection{Data Analysis}

In all papers, a qualitative content analysis of the data material was carried out [84]. Manifest and latent content of the material was examined, with a focus on both the visible components and the underlying meaning of the text [81, 84]. The analytical process was performed in several steps and the authors met regularly to systematically discuss the categorization of the empirical material. Initially, the first author listened and read through the transcripts of multi- 
stakeholder meetings and interviews several times in order to get a sense of the material as a whole. Regarding the multi-stakeholder meetings (Paper I), this resulted in a preliminary thematization of the material contained a description of phases in the meetings (such as discussions about the aim of the meeting, medical condition, rehabilitation and return to work). Based on these phases, the actors' perspectives on work ability were interpreted in collaboration with all authors. The suggested thematization was discussed and revised several times until the authors agreed on a thematic structure that was well grounded in the data material. In the analysis of the interviews, at first broad descriptive categories such as nature of work, sick-leave process, experience of RTW activities, and the role of the welfare system, were generated. In the next step, each case was analysed separately based on these main categories, which in turn came to generate sub-categories where quotations were added with the aim of illustrating each category. Finally, all analysed cases were compared with each other in order to identify a categorization and thematic structure of the material.

\subsubsection{Methodological Considerations}

A strength of Papers II-III is that workers and supervisors are considered simultaneously, in matched pairs. In this way, views and experiences regarding the cases from two different perspectives have been captured, which provides an analytical advantage.

A limitation of all the papers (in particular Papers II-IV) is that the data material consists of a majority of women, where assistant nurse was the dominant occupation, and this may have had an impact on the results. Women in Sweden (as in many other European countries) have a higher degree of sickness absence than men. It is also clear that women employed within the sector of health- and social care (e.g. assistant nurses working in elderly care and hospitals) belong to an occupation category where levels of sickness are among the highest. Sickness absence is also higher in low-waged jobs and among unskilled workers [85]. A majority of the sick-leave cases were identified by employer and union organizations, which may have affected the data selection. It is possible that the cases were considered to be the most successful 
ones (those put forward by employers) or the most difficult ones (those put forward by unions). Another possible limitation is that the interviews conducted with matched pairs might have influenced how open the participants were during the interviews; they might have been concerned about data security and remaining anonymous. The credibility of the papers is strengthened by the discussions and examinations of the co-authors during the analytical process. The emerging findings of the papers have been systematically discussed as continuous quality checks, in order to achieve trustworthiness.

\subsubsection{Ethical Considerations}

The studies were approved by the Regional Ethics Board in Linköping, Sweden. Ethical issues have constantly been discussed and managed by the research team. At an early stage in the research process, risks concerning participants' involvement in the studies were identified and managed with a view to keeping the risks to a minimum. In all studies, the participants were informed about the purpose of the studies and ensured that participation was voluntary. All participants gave their consent to participate and for the status meetings and interviews to be recorded. The studies fulfilled the basic ethical principles for research in social science by informing about the purpose of the study, receiving informed consent, not causing harm to participants and maintaining confidentiality [84]. 


\section{Findings}

The four papers in this thesis had different approaches to studying activation policies and RTW in local practice. In this chapter the main findings of each paper are presented.

\subsection{Paper I: Policy and Practice of Work Ability: A Negotiation of Responsibility in Organizing Return to Work}

Based on theoretical and legal aspects of work ability, the aim of the paper was to analyse the perspectives of welfare state actors and employers on work ability in local practice, by studying recorded multi-stakeholder meetings.

In the analysis, three perspectives on work ability were identified (see Table 3): a medical perspective, a workplace perspective and a regulatory perspective. 
Table 3: The various stakeholders' perspectives on work ability in an RTW context

\begin{tabular}{|c|c|c|c|}
\hline & $\begin{array}{l}\text { Work Ability as a Medical } \\
\text { Question }\end{array}$ & $\begin{array}{c}\text { Work Ability as a Workplace } \\
\text { Question }\end{array}$ & $\begin{array}{c}\text { Work Ability as a Regulative } \\
\text { Question }\end{array}$ \\
\hline $\begin{array}{l}\text { Swedish Social } \\
\text { Insurance } \\
\text { Agency }\end{array}$ & $\begin{array}{l}\text { Work ability is assessed based on } \\
\text { medical certificates and how the } \\
\text { diagnosis affects the ability to } \\
\text { work. }\end{array}$ & $\begin{array}{l}\text { Work ability depends on whether } \\
\text { employers can offer workplace } \\
\text { adjustments. }\end{array}$ & $\begin{array}{l}\text { Work ability as an administra- } \\
\text { tive/bureaucratic category with } \\
\text { the SSIA as a gatekeeper. Work } \\
\text { ability is assessed in fixed per- } \\
\text { centages in relation to criteria } \\
\text { for entitlement to sickness } \\
\text { benefits. }\end{array}$ \\
\hline Healthcare & $\begin{array}{l}\text { Focus on medical treatment and } \\
\text { rehabilitation. }\end{array}$ & $\begin{array}{l}\text { Assessments of work ability are } \\
\text { made despite limited knowledge } \\
\text { of the workplace. }\end{array}$ & $\begin{array}{l}\text { Requirement to adapt work } \\
\text { ability assessments to fixed } \\
\text { percentages based on compen- } \\
\text { sation levels in the sickness } \\
\text { insurance. }\end{array}$ \\
\hline Employers & $\begin{array}{l}\text { Medical impairments as a main } \\
\text { problem for individuals' inability } \\
\text { to work. Employers use medical } \\
\text { statements as expert knowledge } \\
\text { in their assessment of work } \\
\text { ability. }\end{array}$ & $\begin{array}{l}\text { A focus on individuals' lack of } \\
\text { health in relation to workplace } \\
\text { demands. Production perspective } \\
\text { and financial goals of the organi- } \\
\text { zations as important factors. }\end{array}$ & $\begin{array}{l}\text { Employers' possibilities and } \\
\text { willingness to offer adjustments } \\
\text { determine work ability and } \\
\text { return to work, and thereby } \\
\text { influence entitlement to sick- } \\
\text { ness benefits. }\end{array}$ \\
\hline
\end{tabular}

In the discussions, medical assessments served as objective expert statements to legitimize stakeholders' perspectives on work ability and RTW. It was apparent that different regulations and organizational logics influenced different stakeholders' arguments. Healthcare representatives mainly emphasized medical barriers for the individual's RTW, while the SSIA people generally argued from a regulatory point of view, trying to get other stakeholders involved in the individuals' RTW processes. Employers frequently referred to a medical perspective to legitimize the person's sick leave and absence from work, while simultaneously expressing difficulties about making workplace adjustments.

Although the policy ideal of the status meeting was to facilitate stakeholder collaboration and facilitate RTW, the analysis illustrated how the meetings developed into an arena for negotiations about workplace adjustments, rehabilitation efforts and financial support. It became clear that the meetings took 
place in an intersection between organizations with different rules and organizational logics. Although the formal goal of the status meeting was to facilitate stakeholder collaboration and facilitate RTW, the results demonstrated an unequal distribution of power among the actors who were cooperating, where the employers held the "trump card". Employers were influential negotiators because they were able to state that they could or could not accommodate the individual, and this was not questioned by the SSIA.

\subsection{Paper II: Early-Return-to-Work in the Context of an Intensification of Working Life and Changing Employment Relationships}

The aim of this paper was to analyse RTW practice in local workplace contexts, in relation to Swedish early-RTW policy. In the analysis, three themes were identified: 1) intensive workplaces and working conditions 2) employer support - a function of worker value and 3) work attachment and resistance to job transition.

Overall, the findings of this paper illustrate that Swedish early-RTW policy is based on an idealized image of the "standard workplace" with its explicit or implicit assumption that employers and work organizations are able to welcome sick-listed workers back to work in a healthy way. The results of this paper reflect the intensity of modern working life which appeared at odds with the policy ideal of getting sick-listed people back to work early. Workers and supervisors frequently described current working life as demanding, and related how these circumstances affected sick-listed peoples' conditions for sustainable RTW. The findings suggest that the intensity of modern working life leaves limited room for accommodating people with reduced work ability.

Employer strategies tended to be influenced by their notion of the immediate value of the sick-listed worker, in terms of being efficient, possessing social skills and having relevant competence. In the context of stricter activation principles in sickness insurance (early-RTW policy) and work intensification, it was apparent that sick-listed workers were either encouraged in local workplace practice to return to their present job (with or without adjustments), be 
relocated to another job at the workplace, quit by becoming unemployed (in which case the SPES was involved) or retire.

In cases where there was an emphasis on transition (work relocation, unemployment, retirement) it was apparent that supervisors described the transition as a "new opportunity" and as "healthy change" for the sick-listed workers. They underlined how sick-listed workers should not expect to stay at their ordinary workplaces and they should be more entrepreneurial about their own career by changing jobs. While supervisors used the discourse of "new opportunities" and "healthy change" to describe the transition process, workers regularly experienced transition as difficult and unjust. They felt social and emotional attachment to their present job in instances when they had been employed there for many years. They frequently underlined how much they liked their work tasks and co-workers, and how these jobs provided security. They were also left out in the decision-making process of their RTW.

Overall, in the context of early-RTW policy and the intensity of modern working life, the findings of this paper illustrate how a great deal of responsibility was placed on sick-listed workers to be adaptable to workplace demands in order to be able to return and stay at work.

\subsection{Paper III: Return to Work or Job Transition? Employer Dilemmas in Taking Social Responsibility for Return to Work in Local Workplace Practice}

The aim of this paper was to analyse the role and activities of employers with regard to RTW in local workplace practice. The analytical approach to study the role of employers in RTW was based on the three-domain model of social corporate responsibility [86]. The model illustrates the linkage between corporations and their social environment, and consists of three areas of corporate responsibility: economic, legal and ethical.

The findings of the paper illustrate that employers had difficulty taking social responsibility for RTW. Economic considerations regarding their business took precedence over legal and ethical considerations. Hence, it was the needs 
and interests of employers' businesses that guided their role and activities. Legal demands had little practical influence on employers' strategies, since these could support both return to work and transition (see Figure 1).

Figure 1: The relative influence of economic, legal and ethical considerations in employers' RTW activities

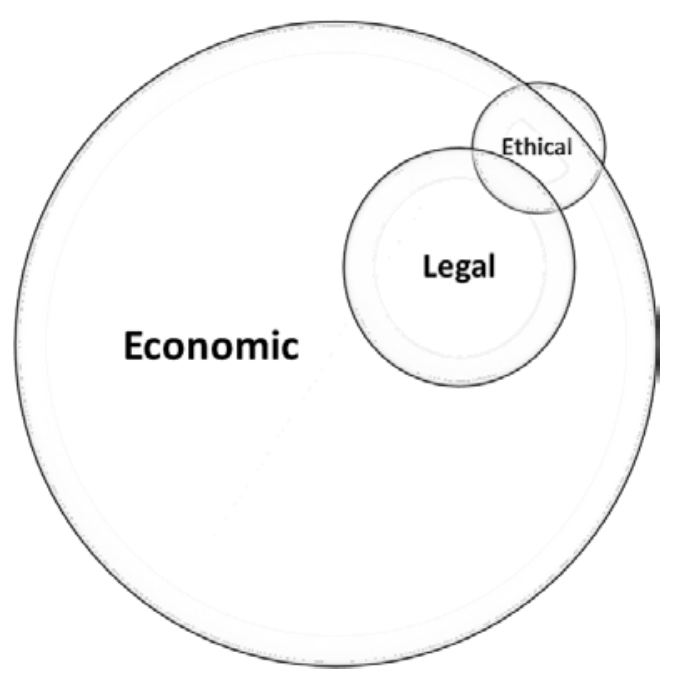

Employers engaged in either "RTW activities" or "transition activities" that were applied differently. Their ability and willingness to take social responsibility for the RTW of sick-listed workers depended to a large extent on how valued the sick-listed workers were considered to be to their business and the nature of the job (e.g. the availability of suitable work adjustments). The results of this study suggest that Swedish legislation and policies do not always adequately prompt employers to get sick-listed workers back to work. 


\subsection{Paper IV: Activation Policies and Sick-Listed Workers' Experiences and Trust in the Sickness Insurance System in Local Practice}

The aim of this paper was to analyse sick-listed workers' experience of the sickness insurance system in contacts with the SSIA and their front-line staff. The paper sheds light on sick-listed workers' experience of the activation policy in the implementation phase, in encounters with the SSIA. Sick-listed workers described their contacts and relations with SSIA officials as heavily standardized. They perceived that SSIA officials followed regulations and organizational demands, with few opportunities to be an involved actor who supported their individual needs. The SSIA was described as having a mainly administrative and controlling function during their sick leave, resulting in a distant relationship. It was also clear that sick-listed individuals experienced activation policies as demanding, and that their sick leave was characterized by insecurity and uncertainty. They perceived that they were objects of suspicion in the sickness insurance system, and emphasized feelings of being mistrusted or not believed by the SSIA regarding their illness and work disability. Overall, this paper suggests that sick-listed workers' trust in the sickness insurance system may be challenged by demanding activation policies including regulations emphasizing time limits and enforcement of standardized work processes at the SSIA. 


\section{Activating the Sick-Listed}

The overall aim of this thesis has been to study the local practice of activation policies by analysing how they are received, implemented and experienced by welfare state organizations, employers and sick-listed workers. In this chapter, the main findings of the papers are elaborated in relation to the theoretical framework presented earlier in this thesis.

\subsection{Organizational Boundaries in Return to Work}

The state has a key role in the development of an organizational field, in terms of establishing rules that other organizations are required to follow [61]. The importance of rules is illustrated in the development of RTW as an organizational field, and the government has introduced activation policies during the last few decades which actors such as welfare state organizations (the SSIA, the healthcare system, the SPES) and employers are required to follow and implement. All of these actors have a common legal obligation and task in terms of getting sick-listed workers back to work. Overall, the main findings of the papers illustrate how the RTW of workers on sick leave is characterized by a complex process imposing heavy demands on those organizations (welfare state organizations and employers) that are required to implement the policy. The findings in this thesis illustrate how welfare state actors and employers in the organizational field of RTW are governed by their own organizational logics and interests; they fail to take a holistic view of the individual and share a common social responsibility for sick-listed workers' RTW processes. For example, in Paper I the multi-stakeholder meetings (held to facilitate collaboration and promote RTW) developed into an arena for negotiations of responsibility regarding workplace adjustments, rehabilitation efforts and financial support. Domain claims were apparent, and actors were competing in avoiding responsibility for the individual [26]. Hence, the multi-stakeholder meeting served to maintain organizational boundaries rather than being a tool 
to overcome them. Cooperation problems in implementing activation policies have also been found in previous research. Studies demonstrate how the actors involved have different perspectives on individuals' work ability and have difficulty cooperating [11-13].

These cooperation difficulties between welfare state organizations can be understood in the context of NPM reforms that have been implemented in the public sector during recent decades. In order to make the public sector more efficient, NPM practices such as management by objectives have come to influence the day-to-day work of front-line staff in street-level bureaucracies $[74,75]$. The focus on accountability is assumed to lead to better organizational performance, improved service and attention to the authorities' "customers" [74, 75, 87]. Meanwhile, organizational research shows that in line with the implementation of these NPM practices, strong organizational identities within the public sector have emerged, in terms of increased autonomy and boundaries between public services. Hence, collaboration may in itself be a popular term to use, but difficult to realize in practice, due to the different regulations, goals and guidelines of organizations [88, 89].

\subsection{Demanding Activation Policies and Sick-Listed Workers' Lack of Trust in the Sickness Insurance System}

In line with the implementation of NPM reforms, research has identified how street-level bureaucrats' room for manoeuvre in client-related work has come to be increasingly restricted by structural limitations [76]. This development was particularly apparent in Paper IV, in sick-listed workers' experiences of contact with the SSIA and their officials. They perceived that SSIA officials followed regulations and organizational demands rather than being an involved actor, supporting their individual needs. In a Swedish social policy context, there have been attempts to directly regulate and control the clientrelated work of SSIA officials. There are both external (legislation) and internal (organizational) demands on standardized work processes [29, 90]. The rehabilitation chain is an example of an regulated working method that SSIA officials are required to apply [29]. 
The findings of Paper IV also indicate a markedly distant relationship with the SSIA, which was seen as a "gatekeeper" in terms of mainly having a controlling and administrative function during the individual's sick leave. Sick-listed workers perceived that the SSIA regarded them as objects of suspicion, and emphasized feelings of not being trusted or believed in, regarding being ill and unable to work. In this context, previous research shows how activation policies with a demanding side consisting of sanction elements (e.g. withdrawal of benefits) may challenge the trust between the client (e.g. the unemployed and sick-listed person) and welfare street-level bureaucrats [9193]. As described in an earlier chapter, the welfare state has taken on a more controlling and administrative function, in that the SSIA's main task today is to assess individuals' entitlement to sickness benefits, and to a lesser extent to engage in the coordination of RTW. The findings of this thesis, illustrate how sick-listed workers experience that measures in Swedish activation policies had a strong focus on demanding aspects (financial work incentives) and less on enabling aspects (investments in skills).

\subsection{Tension between Activation Policies and an Intensive Working Life}

Current activation policies focusing on RTW reflect an explicit or implicit assumption that employers and work organizations are willing and able to welcome sick-listed workers back to work in a healthy way. The focus in social policy on employment promotion rather than on systems of social protection reflects a strong belief that employers and the labour market have the ability to solve sickness absence, and an ideal workplace with stable employment relationships is assumed [5]. However, the main findings from Papers IIII pose a contrast to this ideal of the workplace, by illustrating the intensity of modern working life which appears to be at odds with the policy ideal of getting sick-listed people back to work early. Overall, the findings reflected an intensive and demanding working life, which implied that employers had difficulty in taking social responsibility for RTW. Economic considerations regarding their business took precedence over legal and ethical considerations. Modern working life leaves limited room for accommodating people with 
reduced work ability, who are not considered to have a business value for the workplace. Employers found it difficult to offer workplace adjustments due to business pressure, and needed to balance societal expectations of taking responsibility for RTW with fulfilling the needs of their business. As a consequence, activation policies focusing on RTW may risk being hampered, since in local workplace practice the number of work tasks or jobs to which sicklisted individuals can be returned is limited.

The financially oriented perspective of employers on RTW can be understood in the context of changing working conditions in contemporary working life, where there has been an increase in re-organizations, downsizing and redundancies in work organizations during the last few decades. There is extensive research on the changing nature of working life and employment relations, and how working life is characterized by the intensification of work and high demands on productivity [14-18]. There are studies indicating that current working life is characterized by increased mental demands rather than physical demands [94]. Meanwhile, earlier studies have pointed out that organizational restructuring may imply risks on the physical and mental health and wellbeing of employees [95]. It has been shown that downsizing is associated with increased long-term sick leave among the remaining employees [96, 97].

In a Swedish context, studies indicate that people in a fast-paced, competitive work environment have been excluded from the regular labour market in recent decades [66, 77]. This development is illustrated in the number of people who are coded and registered as "occupationally disabled" at the SPES in Sweden. In 1992, 10\% of all registered unemployed people at the SPES were classified as disabled. In 2011, the figure had risen to $25.3 \%$ [98]. In particular, the number of people classified with mental disabilities has grown. The increased number of people classified as occupationally disabled can be described as a consequence of the greater demands on individuals in working life, where standards of normality have changed [66, 77]. Apart from having the relevant education and work experience, the individual must also have the right attitude and social behaviour in order to be considered "employable" by employers. Individuals are required to possess social skills, be flexible and adaptable [67]. 


\subsection{Employers and the Workplace as the Missing Link}

The findings of this thesis raise questions regarding the role and responsibility of employers in the RTW process. Overall, this thesis illustrates how employers and the workplace appears to be the missing link in the organizational field of RTW. Based on the findings of the papers, it is suggested that Swedish legislation and policies may not always adequately prompt employers to engage in sick-listed workers' RTW process. Regulations appear to give few incentives for employers to actively engage in the process of RTW and collaborate with other actors such as the SSIA.

The degree of interaction between the organizations within an organizational field may differ over time [61]. This is apparent when looking at how the employers' regulative obligations regarding RTW have changed over time. In the early 90s, with the implementation of the so-called rehabilitation reform, the focus was on the central role of the workplace to ensure sick-listed workers' health, work ability and RTW. The political ambitions (policy level) behind the new rehabilitation rules were that the 1990s should be "the decade of good work". Hence, during this period, employers and the workplace explicitly had a central role in the organizational field of RTW. However, in the last decade, policy makers have primarily directed their attention to reforming the social security system in order to solve problems concerning sickness absence [99, 100]. There has been less focus on strengthening incentives for employers to promote RTW [101]. For example, the formal requirement that employers were to establish a rehabilitation plan was abolished in 2007. The main arguments behind this change were that rehabilitation plans contained insignificant information, and that the vast majority of employers did not conduct these investigations anyway [102]. Furthermore, employers are now underrepresented in Swedish cooperation structures regarding sick-listed peoples' RTW [99]. Against this background, today's employers appear to be neglected actors in the organizational field of RTW. Although Swedish employers have a legal responsibility to organize workplace adjustments and engage in RTW, it has been pointed out that there is inadequate control of whether they are fulfilling their obligations $[103,104]$. Overall, Sweden is described as a country where both the legal and the financial incentives for employers to engage in sicklisted workers' RTW processes are comparatively weak [101]. The situation in Sweden can be contrasted with the Netherlands, where employers are required 
to provide wage replacements for up to two years in the event of illness, and where they may be sanctioned when activities in RTW are considered insufficient [32]. In Canada, where the compensation system is generally funded by employers via premiums, financial rebates are given to employers who can demonstrate fewer than the expected number of days of sickness absence due to work injury, and surcharges are imposed for a higher number of days of work injury absences than expected [105]. These so-called experience-rated premiums are assumed to encourage employers to undertake preventive work to reduce injuries and the duration of absence due to sick leave. Meanwhile, financial incentives may result in employers becoming more selective when hiring new employees [106]. As a consequence, this might limit the opportunities for workers with reduced work ability to enter the labour market and find a new job. Other studies have pointed out that employers use different strategies to avoid RTW obligations, such as accommodating the worker [48].

\subsection{Individualization and the Active Sick-Listed Worker as an Ideal}

Due to current activation policies and work intensification, the main findings of Papers II and III reflect that in local workplace practice, sick-listed workers were expected to be active and flexible, and take responsibility for their own RTW process. Sick-listed workers were encouraged to adjust to new workplace settings and environments to meet the demands of the workplace, and, if RTW was not possible, to the demands of the labour market. As such, the findings illustrate an emerging social climate of individualized responsibility in policy and in local workplace practice. In workplace practice, the implementation of the policy often became a matter of fitting the worker to the job, instead of fitting the job to the worker.

The findings in Papers II and III indicate that employers' RTW strategies tended to be influenced by their notion of the immediate value of the sicklisted worker in terms of being efficient, possessing social skills and having relevant competencies. In cases where supervisors did not consider that sicklisted workers had such immediate value, there was an emphasis on transition for the worker. Transition activities were often exit strategies [26] aimed to 
transfer (exit) sick-listed workers away from their original job to another setting, such as work relocation, unemployment or retirement. While supervisors described transition in terms of new opportunities and a healthy change, workers resisted pressure from their employers to be relocated to another job or unemployment. In general, they experienced work adjustments and job transition as difficult and unjust, and felt socially and emotionally attached to their original job. Due to their long-term employment and loyalty they thought their employer owed them the job.

In the light of activation policies focusing on early RTW and an intensive working life, RTW tends to become an individual question, in that it is the sick-listed worker who is expected to "work on herself" in terms of being active and adaptable to return and stay at work. In this individualized view of causes and solutions to sickness absence and RTW, contextual and environmental factors (such as work environment and work organization) are played down. From a critical point of view, these results can be described as a subtle form of governance traced to Foucauldian theory on self-regulation [64-66, 107]. Miller and Rose [65] describe it in terms of advanced liberal governance, where the individual is seen as an active subject who becomes the object of interventions and change. In line with Miller and Rose, the pressure on Swedish sick-listed workers can be seen as an expression of the enterprising self, in that people in modern working life are expected to be active, show entrepreneurial attitudes, and be adaptable to changing circumstances; this is illustrated in the findings of this thesis.

The core elements of activation policies in the Swedish welfare system appear to be the implementation of time limits for sick leave and standardized assessments; however, there is a lack of coordination and enabling measures to support the workplace and individuals' ability to take action for return to work. The findings illustrate an emerging social climate where sick-listed workers - in Swedish activation policies and also in local workplace practice - are active agents who must take responsibility for their sick leave and RTW process. Overall, this thesis suggests that in a Swedish context, RTW is a question of activating the sick-listed rather than activating the workplace. 


\subsection{Conclusions}

Overall, this thesis illustrates how the RTW of workers on sick leave is characterized by a complex process which makes heavy demands on those organizations (welfare state organizations and employers) that are required to implement the activation policies. The main findings of the papers reflect strong organizational boundaries in the implementation process of activation policies, where welfare state actors and employers are governed by their own organizational logics and interests. It is apparent that the actors involved fail to take a holistic view of sick-listed workers and do not share a common social responsibility for the individual's return to work.

This thesis illustrates how current activation policies focusing on RTW are based on an idealized image of the standard workplace. There is an explicit or implicit assumption that employers and work organizations are able to welcome sick-listed workers back to work in a healthy way. However, the findings illustrate a tension between current activation policies and an intensive working life, where employers have difficulty in taking social responsibility for RTW. It is clear that the SSIA's focus on activation and early RTW in several cases clashes with the employers' financially oriented perspective. The main findings indicate that the sick-listed worker's value to the employer's business and the nature of the work (e.g. availability of suitable work adjustments) affect whether employers engage in RTW or not. It appears that the intensity of modern working life leaves limited room for accommodating peo-

ple with reduced work ability, who are not considered to have a business value to the workplace.

The core elements of activation policies in the Swedish welfare system appear to be the implementation of time limits for sick leave and standardized assessments; however, there is a lack of coordination and enabling measures to support the workplace and individuals' ability to take action for return to work. Overall, this thesis illustrates an emerging social climate where sicklisted workers are positioned as active agents who must take responsibility for their sick leave and their RTW process. In a Swedish context, RTW is a matter of activating the sick-listed, rather than activating the workplace. 


\subsubsection{Implications}

- In order to promote sustainable RTW, there is a need for policies that acknowledge and take into account contemporary workplace conditions, such as work intensification and changing employment relationships. The idealistic image of workplaces as welcoming arenas for sick-listed workers needs to be reconsidered.

- Swedish legislation and policies do not always adequately prompt employers to engage in RTW. There is a need for further attention to the organizational conditions required for employers to take social responsibility for RTW in the context of business pressure and work intensification.

- The way in which actors' different organizational logics, interests and power resources affects assessments of work ability and RTW processes needs to be further elucidated.

- Measures in activation policies have had a strong focus on demanding aspects (financial work incentives) and less on enabling aspects (investments in skills), and the results suggest that these could be better balanced. 


\section{Svensk Sammanfattning}

Att minska samhällets kostnader för sjukfrånvaro och få sjukskrivna tillbaka i arbete har de senaste decennierna framförts som några av socialpolitikens viktigaste uppgifter. Inom ramen för denna utveckling har arbetslinjen i socialpolitiken stärkts med en betoning på individers skyldigheter att arbeta. Sjukskrivna förväntas att vara "aktiva” istället för "passiva” mottagare av ekonomisk ersättning. Sedan 2008 har flertalet större förändringar gjorts i sjukförsäkringen, bl.a. införandet av den så kallade rehabiliteringskedjan med fasta tidgränser för bedömningen av arbetsförmåga och en slutgräns för utbetalning av sjukpenning. Strävan ligger på tidig återgång i arbete där omställning ses som en lösning på sjukskrivning. Genom ett byte av arbete förväntas bättre matchning mellan den sjukskrivnes arbetsförmåga och arbetets krav kunna uppnås. Emellertid finns det begränsad kunskap om hur denna aktiveringspolitik med fokus på tidig återgång i arbete upplevs av berörda aktörer. Avhandlingen sätter fokus på aktiveringspolitikens praktik. Huvudsyftet är att studera hur aktiveringspolitiken mottas, implementeras och upplevs av aktörer på lokal nivå (välfärdsorganisationer, arbetsgivare och sjukskrivna). En övergripande ambition är att bidra till ökad kunskap och förståelse för hur förutsättningarna ser ut för återgång i arbete i den lokala praktiken. Fokus ligger framförallt på Försäkringskassans och arbetsgivares roll i återgång i arbete. Men också på de sjukskrivna, vars välfärd blir direkt påverkade av besluten, och hur de upplever åtgärderna och relationer med såväl Försäkringskassan som arbetsgivare. Analysen har influerats av teorier om organisatoriska fält, individualisering, gräsrotsbyråkrater och organisatorisk styrning.

Det övergripande syftet i denna avhandling undersöks i fyra delstudier (artiklar) där varje artikel har sitt specifika syfte. Avhandling bygger på kvalitativa metoder och materialet utgörs av två empiriska studier: 1) ljudupptagningar från avstämningsmöten (med den sjukskrivne och representanter från Försäkringskassan, sjukvården och arbetsgivare) (n=9) och 2) semi-strukturerade intervjuer med sjukskrivna och deras chefer på 18 arbetsplatser $(n=36)$. Avstämningsmötena samlades in 2007 och 2008 i Östergötlands län och intervju- 
erna genomfördes mellan år 2012-2013 i Östergötlands län, Stockholms län och Södermanlands län.

I delstudie 1 var syftet att studera välfärdsaktörers (Försäkringskassan och hälso-och sjukvården) och arbetsgivares perspektiv på arbetsförmåga genom att analysera inspelade så kallade avstämningsmöten. På policynivå har avstämningsmötet presenterats som ett effektivt verktyg i lösningen på problemen med långa sjukskrivningar och hög sjukfrånvaro. Genom att samla involverade aktörer "runt ett bord” (Försäkringskassan, den sjukskrivne, sjukvården, arbetsgivare och Arbetsförmedlingen) förväntas parterna hitta gemensamma lösningar som ska underlätta den sjukskrivnes återgång i arbete. Denna studie visar dock att involverade aktörer hade olika perspektiv på den sjukskrivnas arbetsförmåga. Avstämningsmötena utmärktes av en förhandling om arbetsförmåga och vilka organisationer som hade ansvar för den sjukskrivnes rehabilitering och återgång i arbete. Försäkringskassans fokus på återgång i arbete kom i flera fall på kollisionskurs med arbetsgivarnas synsätt som ofta uttryckte svårigheter att anpassa arbetsplatsen efter den sjukskrivnes behov. Studien visar att det i sista hand är arbetsgivarna som avgör om det är möjligt för den sjukskrivne att återkomma till sitt ursprungliga arbete.

I delstudie 2 var syftet att studera hur regelverket för sjukskrivning med fasta tidsgränser påverkar sjukskrivningsprocessen. Resultaten visar hur arbetsgivare tillämpar olika strategier för sjukskrivna beroende på hur värdefulla de är för deras verksamhet. Analysen visar hur sjukskrivna uppmuntrades att antingen återgå till sitt ordinarie jobb (med eller utan anpassningar), bli omplacerade eller omställning genom att bli arbetssökande eller gå i pension. I de fall där fokus låg på omställning, såg arbetsgivare det ofta som en ny möjlighet och hälsosam förändring och som en utväg i ett intensivt och tidspressat arbetsliv där möjligheter till anpassningar var få. Däremot upplevde sjukskrivna i regel omställning som en svår och orättfärdig process. De ansåg att arbetsgivarna inte fullt ut hade tagit sitt sociala ansvar för återgång i arbete genom ett t.ex. anpassa ordinarie arbete eller erbjuda lämpliga omplaceringar.

I delstudie 3 var syftet att analysera arbetsgivares roll och aktiviter gällande återgång $\mathrm{i}$ arbete. Resultaten visar att arbetsgivare generellt har svårigheter att ta socialt ansvar för sjukskrivnas återgång i arbete. De ekonomiska perspektiven överväger i arbetsgivares åtgärder där deras verksamhetsbehov och intres- 
sen styrde vilka åtgärder de initierade för att underlätta återgång i arbete. Studien visar att regelverken i det svenska systemet i praktiken innebär ett förhållandevis stort spelrum för arbetsgivare att välja vilka åtgärder de genomför för olika medarbetare.

Mot bakgrund av en aktiveringspolitik med insatser som fokuserar på tidig återgång i arbete, syftade delstudie IV att analysera sjukskrivnas erfarenheter av kontakter med Försäkringskassan och deras handläggare. Resultaten illustrerar hur sjukskrivna upplever kontakterna med handläggare på Försäkringskassan som standardiserade: de upplevde att handläggarna var lojala till krav i deras organisation snarare än att vara en involverad aktör som stödde deras individuella behov. Försäkringskassan beskrivs i termer av att vara en "grindvakt" i sjukförsäkringen som huvudsakligen har en administrativ och kontrollerande funktion under deras sjukskrivning. Överlag visar denna studie att aktiveringspolitiken med ett regelverk som betonar fasta tidsgränser och ett upprätthållande av en standardiserad arbetsprocess inom Försäkringskassan, utmanar sjukskrivnas tillit till sjukförsäkringssystemet.

Övergripande slutsatser av denna avhandling är att återgång i arbete som organisatoriskt fält reflekterar starka organisatoriska gränser där välfärdsaktörer och arbetsgivare i hög grad styrs av sina egna regler, intressen och mål. Aktörerna har svårigheter att ta ett gemensamt socialt ansvar för den sjukskrivnes väg tillbaka till arbetslivet. I sjukförsäkringens regelverk finns en inbyggd förväntan på att arbetsgivarna kan ta ett rehabiliteringsansvar genom arbetsplatsanpassning för sjukskrivna. Denna avhandling visar dock att arbetsgivarna i praktiken delvis har svårigheter att ta ett socialt ansvar genom att till exempel kunna erbjuda lämpliga anpassningar. Arbetslivets intensifiering tycks lämna begränsat utrymme för människor med nedsatt arbetsförmåga som inte kan prestera fullt ut. Det finns därför en risk för att sjukskrivnas återgång i arbete försvåras genom att det inte finns några arbeten för den sjukskrivne att återgå till.

Överlag speglar resultaten ett nytt samhällsklimat där sjukskrivna positioneras som aktiva subjekt som kan ta ansvar för sin sjukskrivning och återgång i arbete. I en svensk kontext, blir återgång i arbete en fråga om att aktivera den sjukskrivne snarare än att aktivera arbetsplatsen. 


\section{References}

1. OECD. Transforming Disability into Ability: Policies to promote work and income security for disabled people. Paris 2003.

2. OECD. Sickness, disability and work: Breaking the barriers. A synthesis of findings across OECD countries. Paris: OECD; 2010.

3. Immervoll H. Activation Policies in OECD Countries: An Overview of Current Approaches. 2012.

4. Waddell G, Burton AK. Is Work Good for Your Health and Wellbeing? The Stationery Office, 2006.

5. MacEachen E, Ferrier S, Kosny A, Chambers L. A deliberation on "hurt versus harm' logic in early return to work policy. Policy and Practice in Health and Safety. 2007;5(2):41-62.

6. Proposition 2007/08:136. En reformerad sjukskrivningsprocess för ökad återgång i arbete [A reformed sick-leave process for increased return to work]

7. SOU 2006:86. Mera försäkring och mera arbete [More insurance and more work]. Stockholm: Ministry of Health and Social Affairs. 2006.

8. Van Berkel R, Hornemann Møller, I. Active social policies in the EU: Inclusion through participation? Glasgow: Policy Press 2003.

9. Holmqvist $\mathrm{M}$. The active welfare state and its consequences: A case study of sheltered employment in Sweden. European Societies. 2010;12(2):209-30.

10.Eichhorst W. Bringing the jobless into work? Experiences with activation schemes in Europe and US. Heidelberg: Springer; 2008.

11.Ståhl C, Svensson T, Petersson G, Ekberg K. The Work Ability Divide: Holistic and Reductionistic Approaches in Swedish Interdisciplinary Rehabilitation Teams. Journal of Occupational Rehabilitation. 2009;19(3):264-73.

12.Ståhl C, Svensson T, Petersson G, Ekberg K. A Matter of Trust? A Study of Coordination of Swedish Stakeholders in Return-to-Work. Journal of Occupational Rehabilitation. 2010;20:299-310.

13.Söderberg E, Vimarlund V, Alexandersson K. Experiences of professionals participating in inter-organisational cooperation aimed at promoting clients return to work. Work. 2010;35(2):143-51. 
14.Burchell B, Ladipo D, Wilkingson F, editor. Job Insecurity and Work Intensification. London: Routledge; 2002.

15.Burke RJ, Cooper CL. The organization in crisis: Downsizing, restructuring, and privatization. Oxford: Blackwell 2000.

16.Gowing M, Kraft JD, Quick JC editor. The new organizational reality: Downsizing, restructuring, and revitalization. Washington, DC: American Psychological Association 1997.

17.Gallie D, White M, Cheng Y, Tomlinson M. Restructuring the employment relationship Oxford: Clarendon Press; 1998.

18.Howard A. The changing nature of work. San Francisco: CA: Jossey-Bass; 1995.

19.Esping-Andersen G. The Three Worlds of Welfare Capitalism. Cambridge: Polity Press; 1990.

20.Marshall TH. Citizenship and Social Class: Cambridge University Press; 1950.

21.Social Inusrance Code, (2010:10).

22.Vahlne Westerhäll L. "Det sjukförsäkringsrättsliga arbetsförmågebegreppet i lagstiftning och rättstillämpning" [The work ability concept in sickness insurance legislation and application]. In: Vahlne Westerhäll L, editor. Arbets(o)förmåga - ur ett mångdisciplinärt perspektiv (Work (dis)ability from a multidisciplinary perspective] Stockholm: Santréus förlag 2008.

23.Eichhorst W, Konle-Seidl R. Contingent Convergence: A Comparative Analysis of Activation Policies. Bonn: 2008.

24.Bengtsson M. Towards standby-ability: Swedish and Danish activation policies in flux. International Journal of Social Welfare 2013.

25.Junestav M. Sjukskrivning som politiskt problem: Sociala normer, institutionell förändring och det politiska språket [Sick leave as a political problem: Social norms, institutional change and the political language Arbetsmarknad \& Arbetsliv. 2004;15(4):9-27.

26.Lindqvist R. Att sätta gränser: Organisationer och reformer i arbetsrehabilitering [Setting limits: Organizations and reforms in work rehabilitation]. Umeå: Boréa; 2000.

27.Björnberg U. Social Policy reforms in Sweden: New perspectives on Rights and Obligations. In: Larsson B, Letell M, Thörn H, editor. Transformation of the Swedish Welfare State From Social Engineering to Governance? . Basingstoke: Palgrave 2012. 
28.Nilsing Strid E. The Sick Leave Process: Sick Leave Guidelines, Sickness Certificates, and Experiences of Professionals. Linköping: Linköping University; 2013.

29. Ståhl C, Müssener U, Svensson T. Implementation of standardized time limits in sickness insurance and return-to-work: Experiences of four actors. Disability and Rehabilitation. 2012;34(16):1404-11.

30.Parlamentariska socialförsäkringsutredningen (S 2010:04) Underlagsrapport.

Sveriges socialförsäkringar i jämförande perspektiv: En institutionell analys av sjuk-, arbetsskade- och arbetslöshetsförsäkringarna i 18 OECD-länder 1930 till 2010 [Sweden's social insurances in a comparative perspective: An institutional analysis of the sickness-, workplace injury- and unemployment insurance in 18 OECD countries from 1930 to 2010]. Stockholm: Erlanders Sverige AB

31.Johnson B. Kampen om sjukfrånvaron [The struggle in connection with sickness absence]. Halmstad Arkiv förlag; 2010.

32.Lippel K, Lötters F. Public insurance systems: A comparison of cause-based and disability-based income support systems. In: Loisel P, Anema H, editor. Handbook of Work disability: Prevention and Management: Springer 2013.

33.Blonk R, Brenninkmeijer V, Lagerveld SE, Houtman ILD Return to work: A comparison of two cognitive behavioural interventions in cases of workrelated psychological complaints among the self-employed. Work \& Stress. 2006;20(2):129-44.

34.van der Klink J, Blonk RWB, Schene AH, van Dijk FJ. Reducing long-term sickness absence by activating intervention in adjustment disorders: A cluster randomised controlled design. Occupational and Environmental Medicine. 2003;60(6):429-37.

35. Anema J, Steenstra IA, Bongers PM, de Vet HCW, Knol DL, van Mechlen W Multidisciplinary rehabilitation for subacute low back pain: Graded activity or workplace intervention or both? A randomized controlled trial. Spine. 2007;32(3):291-8.

36.Loisel P, Abenhaim L, Durand P, Esdaile JM, Suissa S, Giosselin L. A populationbased, randomised clinical trial on back pain management. Spine. 1997;22(24):2911-8.

37. Arends I, van der Klink JCL, van Rhenen W, de Boer MR, Bültmann U. Prevention of recurrent sickness absence in workers with common mental 
disorders: Results of a cluster- randomised controlled trial. Occup Environ Med 2014;71:21-9.

38. Abenhaim L, Rossignol M, Valat JP, Nordin M, Avouac B, Blotman F et al. The role of activity in the therapeutic management of back pain. Report of the International Paris Task Force on Back Pain. Spine. 2000;25(4):1S-33S.

39.Friedman PJ. Predictors of work disability in work-related upper-extremity disorders. Journal of Occupational and Environmental Medicine. 1997;39(4):339-43.

40.Kuoppala J, Lamminpaa A. Rehabilitation and work ability: A systematic literature review. Journal of Rehabilitation Medicine. 2008;40(10):796-804.

41.Franche R-L, Cullen K, Clarke J, Irvin E, Sinclair S, Frank J et al. Workplacebased return-to-work interventions: A systematic review of the quantitative literature. Journal of Occupational Rehabilitation. 2005;15(4):607-31.

42.Krause N, Dasinger LK, Neuhauser F. Modified work and return to work: A review of the literature. Journal of Occupational Rehabilitation 1998;8(2):113-39.

43.Shaw W, Robertson MM, McLellan RK, Verma S, Pransky G. A controlled case study of supervisor training to optimize response to injury in the food processing industry. Work. 2006;26(2):107-14.

44. Hees HL, Nieuwenhuijsen K, Koeter MWJ, Bültmann U, Schene AH Towards a New Definition of Return-to-Work Outcomes in Common Mental Disorders from a Multi-Stakeholder Perspective. PLoS ONE 2012;7(6):1-7.

45.Loisel P, Buchbinder R, Hazard R, Keller R, Scheel I, van Tulder M, Webster B. Prevention of work disability due to musculoskeletal disorders: The challenge of implementing evidence. Journal of Occupational Rehabilitation 2005;15(4):507-24.

46.Ekberg K, Wåhlin C, Persson P, Bernfort L, Öberg B. Is mobility in the labor market a solution to sustainable return to work for some sicklisted persons? Journal of Occupational Rehabilitation. 2011;21:355-65.

47.Costa-Black KM. Core Components of Return-to-Work Interventions In: Loisel P, Anema H, editor. Handbook of Work Disability: Prevention and Management Springer 2013.

48. MacEachen E, Kosny A, Ferrier S. and Chambers L. The "toxic dose" of system problems: Why some injured workers don't return to work as expected. Journal of Occupational Rehabilitation. 2010;20(3):349-66. 
49. Young AE, Roessler RT, Wasiak R, McPherson KM, van Poppel MN, Anema JR. A developmental conzeptualization of return to work. Journal of Occupational Rehabilitation 2005;15(4):557-68.

50.De Vries G, Koeter MWJ, Nabitz U, Hees HL, Schene AH. Return to work after sick leave due to depression: A conceptual analysis based on perspectives of patients, supervisors and occupational physicians. . Journal of Affective Disorders. 2012;136(3):1017-26.

51.Haafkens J, Kopnina H, Meerman MGM, Van Dijk, FJH. Facilitating Job Retention for Chronically Ill Employees: Perspectives of Line Managers and Human Resource Managers. BMC Health Services Research 2011;11(104).

52. Holmgren K, Ivanoff SD. Supervisors' views on employer responsibility in the return to work process. A focus group study. Journal of Occupational Rehabilitation 2007 17(1):93-106.

53.Lemieux P, Durand M, Hong QN. Supervisors' perception of the factors influencing the return to work of workers with common mental disorders. Journal of Occupational Rehabilitation. 2011;21(3):293-303.

54.Nieuwenhuijsen K, Verbeek J, De Boer AGEM, Blonk RWB, Van Dijk FJH. Supervisory behavior as a predictor of return to work in employees absent from work due to mental health problems. Occupational and Environmental Medicine. 2004;61(10):817-23.

55.Tjulin Å, MacEachen E, Ekberg K. Exploring workplace actors' experiences of the social organization of return-to-work. Journal of Occupational Rehabilitation. 2009;20(3):311-21.

56.Wynne-Jones G, Buck R, Porteous C, Cooper L, Button L A, Main CJ. What happens to work if you're unwell? Beliefs and attitudes of managers and employees with musculoskeletal pain in a public sector setting. Journal of Occupational Rehabilitation. 2011;21(1):31-42.

57. Andersen M, Nielsen KM, Brinkmann S. Meta-synthesis of qualitative research on return to work among employees with common mental disorders. . Scand J Work Environ Health. 2012;38:93-104.

58.Tjulin Å, MacEachen E, Stiwne E E, Ekberg K. The social interaction of return to work explored from co-workers' experiences. Disability and Rehabilitation. 2011;33(21-22):1979-89.

59.Dunstan D, MacEachen E. Bearing the brunt: Co-workers' experiences of work reintegration processes. Journal of Occupational Rehabilitation. 2013;23(1):44-54. 
60.Scott R, Meyer, JW. Institutional Environments and Organizations: Structural Complexity and Individualism. Thousand Oaks: SAGE Publications; 1994.

61.DiMaggio PJ, Powell, WW. The Iron Cage Revisted: Institutionalized Isomorphism and Collective Identity in Organizational Fields. American Sociology Review. 1983;48(2):147-60.

62.DiMaggio PJ. State expansion and Organizational Fields. In: Hall RH, Quinn RE, editor. Organizational Theory and Public Policy. London: SAGE; 1983.

63.The Swedish Work Environment Authority's Statute Book: Work adjustments and rehabilitation (1994).

64.Fogde M. The work of job seeking: Studies on career advice for white-collar workers. Örebro: Örebro University 2007.

65. Miller P, Rose N. Governing the Present. Cambridge Polity; 2008.

66.Garsten C, Jacobsson K. Sorting people in and out: the plasticity of the categories of employability, work capacity and disability as technologies of government. Ephemera. 2013;13(4):825-50.

67.Garsten C, Jacobsson K, editor. Learning to be employable: New agendas on work, responsibility and learning in a globalizing world. Basingstoke: Palgrave Macmillan; 2004.

68.Peralta Prieto J. Den sjuka arbetslösheten [The sick unemployment]. Uppsala: Uppsala University 2006.

69.Peralta Prieto J. Arbetsförmedlare som mäklare och terapeuter [Public employment officers as agents and therapists]. In: Garsten C, Thedvall R, Lindvert J, editor. Arbetets marknad: Arbetsmarknandens nya organisering [The labour's market: The labour market's new organization]. Malmö: Liber 2011.

70.Ståhl C, Gustavsson M, Böhm L. 2014:16. Implementering och användning av motiverande samtal (MI) inom Försäkringskassan [Implementation and use of Motivational Interviewing within the Swedish Social Insurance Agency ]. Stockholm 2014.

71.Seing I. Möjligheternas arbetsmarknad? Specialister bedömer "arbetsförmåga” [A labour market of opportunities? Specialists assess "work ability"]. In: Garsten C, Thedvall R, Lindvert J, editor. Arbetets marknad: Arbetsmarknadens nya organisering [The labour's market: The labour market's new organization]. Malmö: Liber 2011.

72.Lipsky M. Street-Level Bureaucracy: Dilemmas of the Individual in Public Service. New York Russell Sage Foundation; 2010. 
73.Johansson R. Vid byråkratins gränser: Om handlingsfrihetens organisatoriska begränsningar i klientrelaterat arbete [On the borders of the bureaucracy: On organizational restrictions in client-related work]. Lund: Arkiv Förlag 1992.

74.Hood C. A public management for all seasons? Public Administration. 1991;69(1):3-19.

75.Pollitt C, Bouckaert G. Public Management Reform. 2nd ed. New York Oxford University Press; 2004.

76.Brodkin EZ. Policy work: Street-level organizations under new managerialism. Journal of Public Administration Research and Theory 2011;21(2):253-77.

77.Jacobsson K, Seing I. En möjliggörande arbetsmarknadspolitik? Arbetsförmedlingens utredning och klassificering av klienters arbetsförmåga, anställbarhet och funktionshinder [An enabling labour market policy? The public employment service's assessment and classification of clients' work ability, employability and disability]. Arbetsmarknad och Arbetsliv [Labour market and Working life]. 2013;19(1):9-24.

78.Berger P, Luckmann T. The social construction of reality: A treatise in the sociology of knowledge New York: Anchor books; 1967.

79.Kvale S, Brinkmann S. Den kvalitativa forskningsintervjun. Lund: Studentlitteratur; 2014.

80.Patton MQ. Qualitative research \& evaluation methods 3. ed. London: SAGE; 2002.

81.Graneheim U, Lundman B. Qualitative content analysis in nursing research: Concepts, procedures and measures to achieve trustworthiness. Nurse Education Today. 2004;24(2):209-30.

82. Hsieh HF, Shannon SE. Three Approaches to Qualitative Content Analysis. Qualitative Health Research. 2005;15(9):1227-88.

83.Hesse-Biber SN, Leavy P. Feminist research practice: A primer. Thousand Oaks: SAGE Publications; 2007.

84.Patton MQ. Qualitative research \& evaluation methods. 3rd ed. London: SAGE; 2002.

85.Försäkringskassan [The Swedish Social Insurance Agency]. Sjukskrivningar i olika yrken under 2000-talet: Antal ersatta sjukskrivningsdagar per anställd år 2002-2010 [Sick-listing in different occupations during the 2000s: Number of compensated sickness days per employee, 2002-2010]. Stockholm: The Swedish Social Insurance Agency 2012 Contract No.: ISSN 1654-8574. 
86.Schwartz MS, Archie B. Corporate social responsibility: A three-domain approach. Business Ethics Quarterly. 2003;13(4):503-30.

87. Hughes OE. Public management and administration: an introduction. New York Palgrave; 2003.

88. Brunsson N, Sahlin-Andersson K. Constructing Organizations: The Example of Public Sector Reform Organization Studies. 2000;21(4).

89.Premfors R, Ehn P, Haldén E, Sundström G. Demokrati \& Byråkrati [Democracy \& Bureaucracy]. Lund: Studentlitteratur; 2003.

90.Hetzler A. Delaktighet under hot: Den nya förvaltningen [Participation under threat: The new public administration]. Malmö: Bokbox; 2009.

91. MacEachen E, Kosny A, Ferrier S, Lippel K, Neilson C, Franche RL, Pugliese D. The ideal of consumer choice in social services: challenges with implementation in an Ontario injured worker vocational retraining programme Journal of Disability and Rehabilitation 2013;35(25):2171-9.

92.Walter L. Arbetsförmedlingens dubbla funktion: Att stödja och att kontrollera [The double role of the Public Employment Service: To support and control]. In: Garsten C, Lindvert, J, Thedvall, $\mathrm{R}$ editor. Arbetets marknad: Arbetsmarknadens nya organisering [The labour's market: The new organization of the labour market]. Malmö: Liber 2011.

93.Bejerot E, Hasselbladh, H. Professional Autonomy and Pastoral Power: The Transformation of Quality Registers in Swedish Health Care. Public Administration. 2011;89(4):1604-21.

94.Hellgren J, Sverke M, Näswall K. Changing work roles: new demands and challenges In: Näswall K, Hellgren J, Sverke M, editor. The Individual in the Changing Working Life Cambridge Cambridge University Press 2008.

95.Bohle P, Quinlan M, Mayhew C. The Health and Safety Effects of Job Insecurity: An Evaluation of the Evidence. Economic and Labour Relations Review. 2001;12(1):32-60.

96.Vahtera J, Kivimäki M, Pentti J, Theorell T. Effect of change in the psychosocial work environment on sickness absence: A seven year follow up of initially healthy employees. Journal of Epidemiology and Community Health. 2000;54(7):484-93.

97.Vahtera J, Kivimäki M, Pentti J. Effect of organisational downsizing on health of employees. Lancet. 1997;350(9085):1124 - 8.

98.Arbetsförmedlingen [The Swedish Public Employment Service]. Statistikenheten [The statistical unit] 2011. 
99.Ståhl C. Samverkan kring återgång i arbete: Var är arbetsgivarna? [Cooperation on return to work: Where are the employers?]. Socialmedicinsk Tidskrift. 2009;86(3):265-74.

100.Melén D. Med arbetsförmåga, utan anställningsbarhet [With work ability, without employability]. Socialmedicinsk Tidskrift. 2009;86(3):265-74.

101.OECD. Sickness, disability and work: Breaking the barriers. Sweden: Will the Recent Reforms Make it? 2009.

102.SOU 2006:107. Fokus på åtgärder: En plan för effektiv rehabilitering i arbetslivet [Focus on measures: A plan for an effective rehabilitation in working life] Stockholm: Ministry of Health and Social Affairs; 2006.

103.Bergendorff S. Rehabilitering - ett långt lidandes historia [Rehabilitation - a long history of suffering]. Sverige 2006.

104.Riksrevisionen [The Swedish National Audit Office]. Tas sjukskrivnas arbetsförmåga tillvara? Försäkringskassans kontakter med arbetsgivare [Is the sick-listed workers' work ability concidered? The Swedish Social Insurance Agency's contacts with employers]. Stockholm 2007.

105.Mansfield L, MacEachen E, Tompa E, Kalcevich CA Critical review of literature on experience-rating in workers' compensation systems. Policy and Practice in Health and Safety 2012;10(1):3-25.

106.van Oorschot W, Boos K. The Battle Against Numbers: Disability Policies in the Netherlands. European Journal of Social Security. 2000;2(4):343-61.

107.Rose N. Powers of Freedom Cambridge: Cambridge University Press; 1999. 



\section{Papers}

The articles associated with this thesis have been removed for copyright reasons. For more details about these see:

http://urn.kb.se/resolve?urn=urn:nbn:se:liu:diva-112400 